\section{Pacific Northwest}

National Laboratory

Operated by Battelle for the

U.S. Department of Energy

\title{
A Radiological Survey Approach to Use Prior to Decommissioning: \\ Results from a Technology Scanning and Assessment Project Focused on the Chornobyl NPP
}
A Milchikov
B Poralo
M Davidko
G Hund

March 1999

Prepared for the U.S. Department of Energy

under Contract DE-AC06-76RL01830 


\title{
DISCLAIMER
}

This report was prepared as an account of work sponsored by an agency of the United States Government. Neither the United States Government nor any agency thereof, nor Battelle Memorial Institute, nor any of their employees, makes any warranty, express or implied, or assumes any legal liability or responsibility for the accuracy, completeness, or usefulness of any information, apparatus, product, or process disclosed, or represents that its use would not infringe privately owned rights. Reference herein to any specific commercial product, process, or service by trade name, trademark, manufacturer, or otherwise does not necessarily constitute or imply its endorsement, recommendation, or favoring by the United States Government or any agency thereof, or Battelle Memorial Institute. The views and opinions of authors expressed herein do not necessarily state or reflect those of the United States Government or any agency thereof.

\author{
PACIFIC NORTHWEST NATIONAL LABORATORY \\ operated by \\ BATTELLE \\ for the \\ UNITED STATES DEPARTMENT OF ENERGY \\ under Contract DE-AC05-76RL01830
}

Printed in the United States of America
Available to DOE and DOE contractors from the Office of Scientific and Technical Information,
P.O. Box 62, Oak Ridge, TN 37831-0062;
ph: (865) 576-8401
fax: $(865)$ 576-5728
email: reports@adonis.osti.gov

\begin{abstract}
Available to the public from the National Technical Information Service, U.S. Department of Commerce, 5285 Port Royal Rd., Springfield, VA 22161 ph: (800) 553-6847 fax: $(703) 605-6900$ email: orders@ntis.fedworld.gov online ordering: http://www.ntis.gov/ordering.htm
\end{abstract}

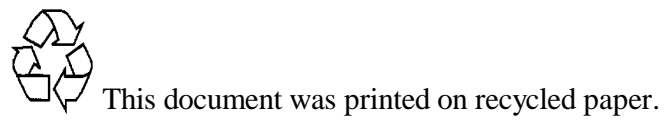




\title{
A RADIOLOGICAL SURVEY APPROACH TO USE PRIOR TO DECOMMISSIONING:
}

\section{RESULTS FROM A TECHNOLOGY SCANNING AND ASSESSMENT PROJECT FOCUSED ON THE CHORNOBYL NPP}

\author{
Prepared by: \\ Aleksey Milchikov and \\ Marina Davidko \\ Slavutych Laboratory of International Research and Technology \\ and \\ Bogdan Poralo, Chornobyl Center
}

With support from:

Gretchen Hund, Battelle

March 1999 


\section{TABLE OF CONTENTS}

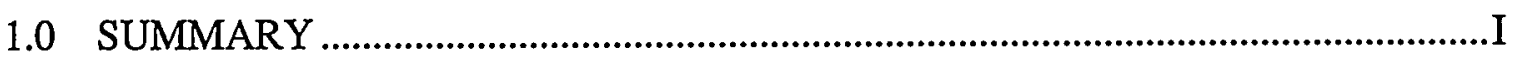

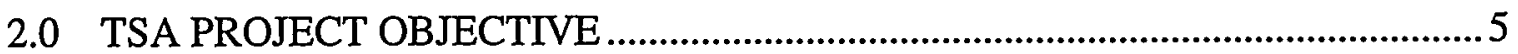

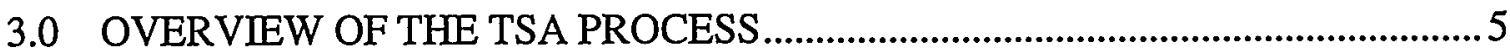

3.1 Needs Assessment............................................................................................5

3.2 Technology Scanning ...................................................................................

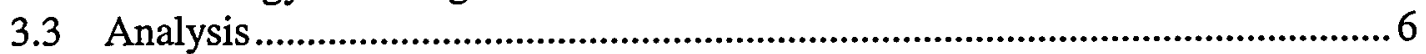

3.4 Delivery and Support for Use...........................................................................

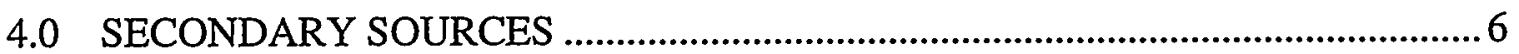

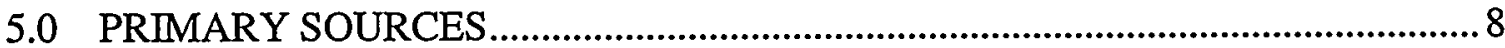

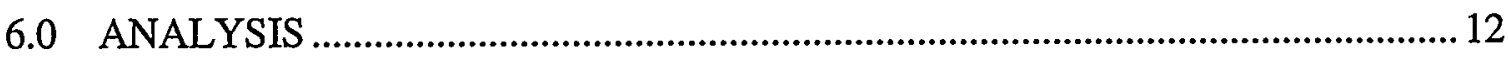

6.1 Regulations, Guidelines, and Methods......................................................... 12

6.1.1 Decommissioning Overview ................................................................ 12

6.1.2 Objective of Characterization............................................................ 13

6.1.3 Radiological Characterization Process................................................ 14

6.1.3.1 Historical Investigation ...................................................................15

6.1.3.2 Data Quality Objectives (DQO) ......................................................16

6.1.3.3 Sampling and Analysis Plan (SAP) ....................................................17

6.1.3.4 Technology Assessment and Integration..............................................18

6.1.3.5 Characterization Survey .......................................................................18

6.1.3.6 Data Quality Assessment..................................................................19

6.1.3.7 Radiation Characterization Final Report ............................................19

6.2 Technology Needs Identified for Radiological Surveying................................20

6.2.1 Scanning Measurement Techniques....................................................21

6.2.1.1 Scanning for Photon Emitting Radionuclides ....................................22

6.2.1.2 Scanning for Alpha Emitting Radionuclides ......................................22

6.2.1.3 Scanning for Beta Emitting Radionuclides ......................................22

6.2.2 Direct Measurement Techniques..........................................................22

6.2.2.1 Direct Measurements for Photon Emitting Radionuclides ................23

6.2.2.2 Direct Measurements for Alpha Emitting Radionuclides...................23

6.2.2.3 Direct Measurements for Beta Emitting Radionuclides .....................24

6.3 Technology Selection Criteria............................................................................2

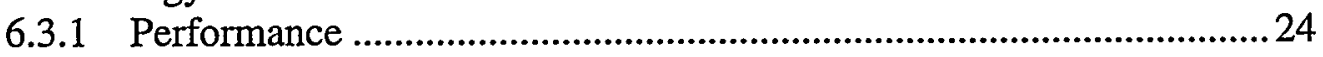

6.3.2 Limitations/Utility Requirements........................................................25

6.3.3 Experience of Applying ..................................................................25

6.3.4 Cost/Delivery Support............................................................................25

6.3.5 Applying the Criteria.................................................................................26

6.4 Technology Scanning Analysis: An Example...................................................26

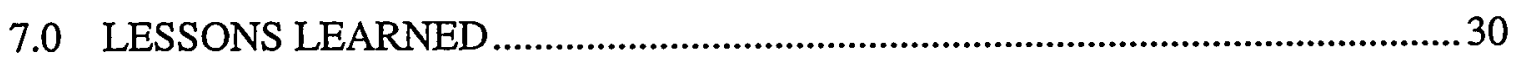

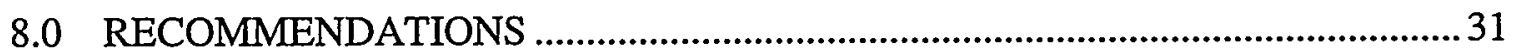


APPENDIX A. Matrix of Secondary Sources Reviewed ......................................................36

APPENDIX B. Results of Charles Thomas' Radiological Investigation of Two Graphite

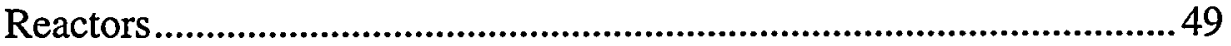

APPENDIX C. Radiation Detectors and Systems ............................................................50

APPENDIX D. Chornobyl TSA Project - Updated March 31, 1999................................60 


\section{LIST OF FIGURES AND TABLES}

Figure $1.1 \quad$ Radiological Characterization Process..................................................... 2

Figure 1.2 Technology Assessment and Selection Process ..............................................4

Figure 6.1 General Decommissioning Process........................................................ 13

Figure 6.2 Radiological Characterization Process...................................................... 14

Table $5.1 \quad$ Primary Information Sources ............................................................... 9

Table 6.3 Radionuclide Inventory Data Needs, Uses, and Collection Methods .......2 21

Table 6.4 Suppliers of Various Instrumentation for Neutron/Beta/Gamma

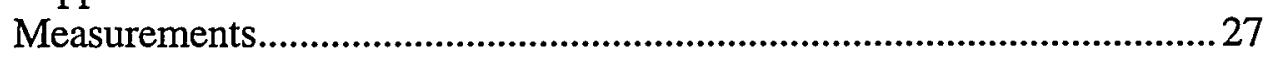

Table 6.5 Example of Radiological Survey Technologies for the ChNPP Prior to

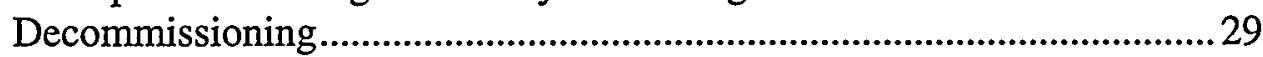

Table B-1 Elemental Concentrations (in ppm) in Two Graphite Reactors .................49

Table B-2 Radionuclide Concentration in Reactor Graphite .......................................49

Table C-1 Radiation Detectors with Applications to Gamma Surveys.........................50

Table C-2 Radiation Detectors with Applications to Gamma and X-Ray Surveys ... 51

Table C-3 Radiation Detectors with Applications to Alpha Surveys...........................53

Table C-4 Radiation Detectors with Applications to Alpha Surveys.............................54

Table C-5 Radiation Detectors with Applications to Beta Surveys ..............................56

Table C-6 Radiation Detectors with Applications to Beta Surveys ...............................57

Table C-7 Radiation Detectors with Applications to Radon Surveys ...........................58

Table C-8 Systems that Measure Atomic Mass or Emissions........................................59 


\subsection{SUMMARY}

The primary objectives of this project are to learn how to plan and execute the Technology Scanning and Assessment (TSA) approach by conducting a project and to be able to provide the approach as a capability to the Chornobyl Nuclear Power Plant (ChNPP) and potentially elsewhere. A secondary objective is to learn specifics about decommissioning and in particular about radiological surveying to be performed prior to decommissioning to help ChNPP decision makers.

TSA is a multi-faceted capability that monitors and analyzes scientific, technical, regulatory, and business factors and trends for decision makers and company leaders. It is a management tool where information is systematically gathered, analyzed, and used in business planning and decision making. It helps managers by organizing the flow of critical information and provides managers with information they can act upon.

The focus of this TSA project is on radiological surveying with the target being ChNPP's Unit 1. This reactor was stopped on November 30, 1996. At this time, Ukraine failed to have a regulatory basis to provide guidelines for nuclear site decommissioning. This situation has not changed as of today. A number of documents have been prepared to become a basis for a combined study of the ChNPP Unit 1 from the engineering and radiological perspectives. The results of such a study are expected to be used when a detailed decommissioning plan is created.

A Comprehensive Engineering Radiological Survey has been written for Unit 1 and is calling for two stages of work. The first stage is an examination of the unit before the fuel is removed; and the second is an examination of the unit after the fuel is removed. All fuel is planned to be removed by 2004 .

For decommissioning to occur safely and efficiently, the radiological status of the buildings, equipment, and the systems of the unit need to be determined prior to decommissioning. The results of the TSA Team's study are aimed to support designing this characterization survey of Unit 1 as well as for the Unit 2. (Recently, the decision was made to decommission Unit 2 as well.) All the information sources regarding rules, regulations and instructions concerning the characterization survey process should be helpful to governmental bodies and supporting organizations preparing the regulatory basis for the future decommissioning processes.

For nuclear facilities, decommissioning is the final phase in the life-cycle after siting, design, construction, commissioning and operation. It is a complex process involving activities such as decontamination, dismantling and demolition of equipment and structures, and management of resulting waste, while taking into account aspects of health and safety of the operating personnel and the general public, as well as protection of the environment.

A good estimate of the amount and type of radioactivity in a nuclear facility is important because it can affect the whole approach to decommissioning, including the choice of the 
time to start decommissioning and the desirability of delay between stages. In addition, such an estimate will be a great asset in the planning phase to ensure that the facility is decommissioned in a safe, economic, and timely manner. This information will assist the planners in determining factors such as the need for decontamination, shielding or remotely operated equipment, waste management and disposal, and potential radiation exposures to the work force. Figure 1.1 is a flow diagram of the entire radiological characterization process.

\section{Figure 1.1 Radiological Characterization Process}

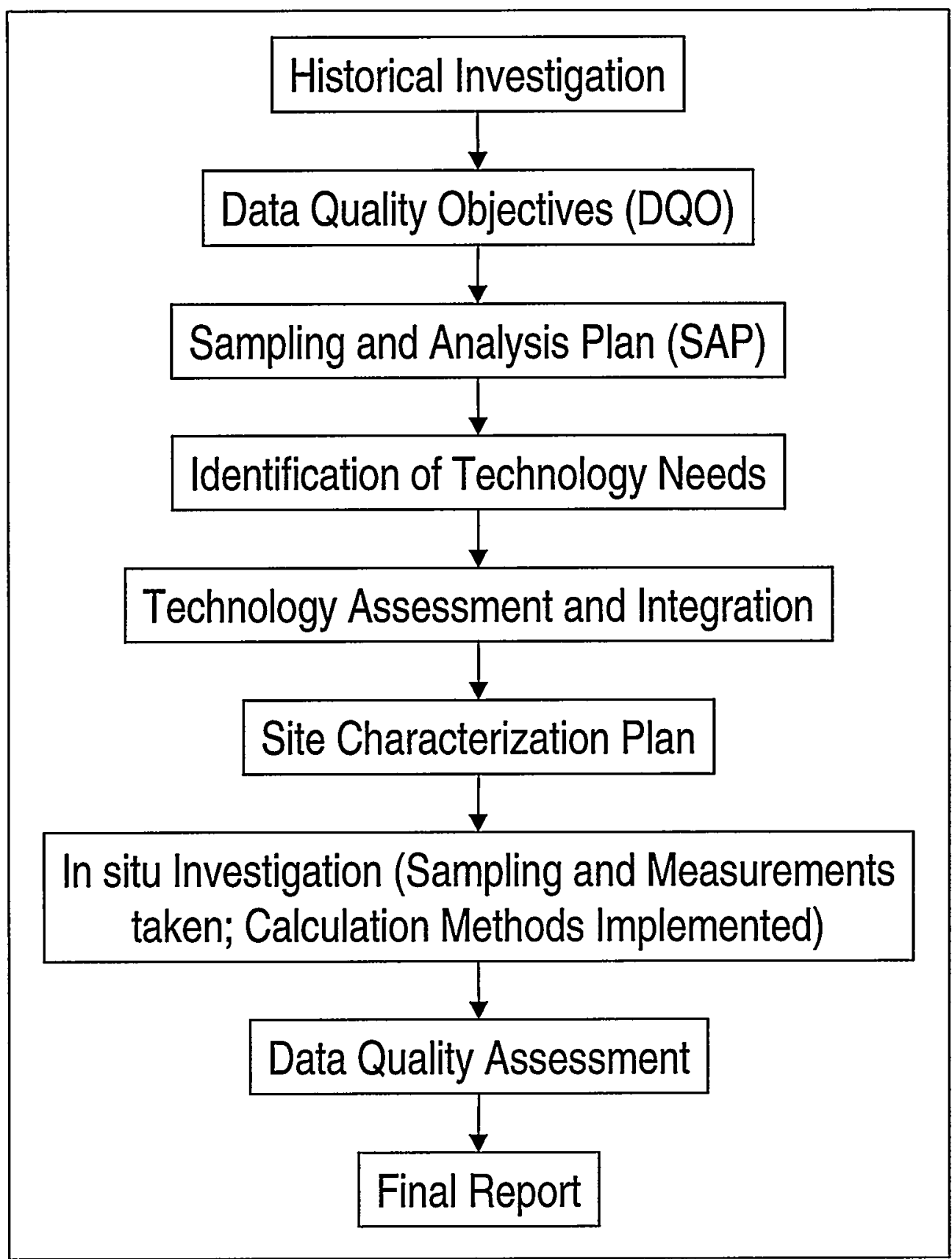


To obtain the radiological survey data, two measuring methodologies are used:

- In-situ measurements;

- Laboratory measurements.

This project focused on gathering information on conducting radiological surveys and manufacturers of equipment used in conducting in-situ measurements. Regulatory/ methods documents classify the following types of in-situ measurements:

- Direct measurements;

- Scanning measurements;

- Sampling.

In-situ measurement sampling is the process of collecting samples and sending them to a laboratory for analysis. Usually, ordinary mechanical, cutting, and drilling instruments are used to collect samples. Thus, only the instruments for scanning and taking direct measurements were analyzed under this project.

A number of sources were used to obtain information about recommended technologies for in-situ scanning and direct measurements. This report contains an entire list of the recommended types of technologies. Priority was given to systems equipped with a computerized capability of data collection and processing. The technologies were evaluated using the following criteria:

1. Performance

- Sensitivity

- Accuracy

- Other characteristics specific for a particular instrument.

2. Limitation/utility requirements

3. Experience of applying

4. Cost/delivery support

Regulatory requirements were also used to help prioritize technology needs and actual technologies to be selected. Figure 2 is a schematic of the technology assessment and selection process. 


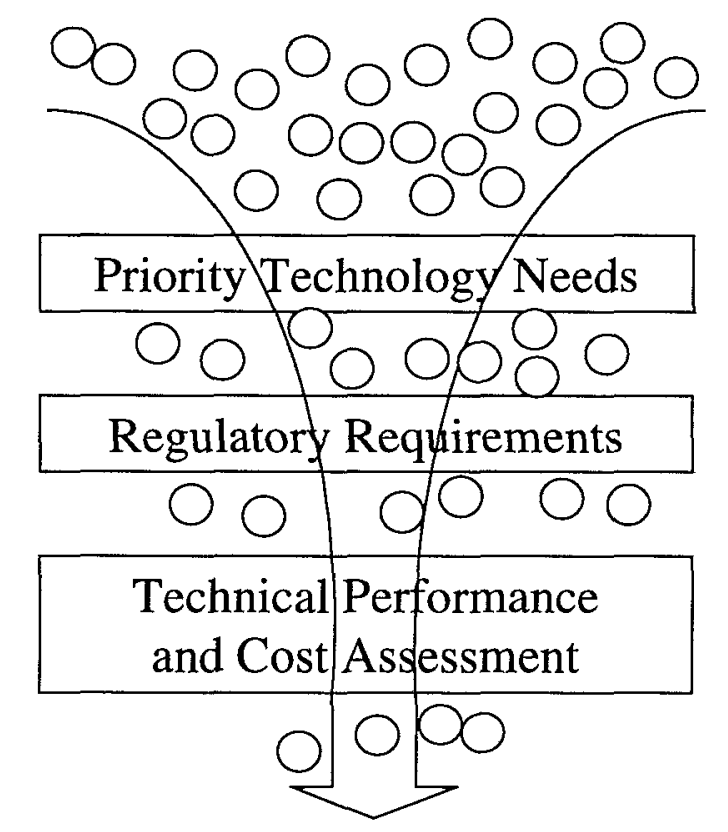

\section{Technologies Selected for Deployment}

As an example of a comparative technology analysis, two competing systems for scanning gamma radiation were examined. RadScan is owned by BNFL and GammaCam is owned by AIL. Advantages and disadvantages for each technology were identified and summarized.

From conducting this project, the Team feels that TSA is an important tool for identifying and analyzing information in any problem area where one has to deal with large amounts of data. One of the stages in the TSA process is working with "secondary" sources (e.g., published materials, website information). TSA requires access to the Internet and a powerful search mechanism (like Dialog) to scan for information sources. Secondary sources identified are important but not as critical as information gained from important "primary" sources (experts in the field). Sometimes it requires using the secondary sources to identify appropriate primary sources.

As a next step, the TSA Team plans to deliver the findings of this project to the team members' organizations -- the Chornobyl Center and the Slavutych Laboratory of International Research and Technology (SLIRT). This presentation is to be followed by a presentation to the relevant Ukrainian regulatory organizations and to ChNPP staff and organizations responsible for decommissioning. There will be an attempt to implement TSA as an on-going function to supply management and staff of the TSA Team's organizations with timely information. Opportunities to provide TSA services to other organizations will also be sought. 


\subsection{TSA PROJECT OBJECTIVE}

The main objectives of this project are to learn how to plan and execute a TSA approach by conducting a project and to provide TSA as a capability to the Chornobyl Nuclear Power Plant (ChNPP) and potentially elsewhere. A secondary objective is to learn specifics about decommissioning and in particular about radiological surveying to be performed prior to decommissioning to help ChNPP decision makers. The knowledge sought includes understanding how the United States and other countries conduct their decommissioning programs on reactors, and other nuclear related facilities, and specifically the radiological survey component prior to actual decommissioning.

\subsection{OVERVIEW OF THE TSA PROCESS}

\subsection{Needs Assessment}

The first step of TSA is assessing the need. What information will be most useful to the client? The client needs to be someone who has authority to make a decision and the information provided by the TSA process needs to be such that the decision maker can act on the information. TSA reports that collect dust are NOT the intent of the TSA process.

During the Summer and Fall of 1998, discussions took place among the Pacific Northwest National Laboratory (PNNL), the Chornobyl Center, and the SLIRT to determine how best to conduct a pilot project on TSA. The decision was made to focus the project on decommissioning of Chornobyl reactors. In narrowing the scope for the pilot project, interviews were conducted with PNNL staff supporting decommissioning efforts at ChNPP and with Ukrainian individuals working on the decommissioning of ChNPP. Suggestions made by the interviewees were later assessed and combined. It was proposed that the TSA pilot project focus on radiological surveying prior to decommissioning. The proposal was forwarded to the managers of the Chornobyl Center and the SLIRT for their confirmation.

One staff person from each institute was selected to come to the United States and conduct the project. In addition, an interpreter came to support the team. These three individuals spent the month of March 1999 conducting the following TSA steps described below.

\subsection{Technology Scanning}

The second step of the TSA process is technology scanning - gathering all of the relevant information and data to support the project. This can be a time-consuming step unless it is well organized. It is critical to efficiently identify the critical sources and order them quickly, particularly for short-term projects where the results are needed quickly. 
The first two weeks of this TSA project were spent searching, gathering, and processing data from the so-called "secondary" sources, that is, from journals, newsletters, and other publications related to the field. The search system called Dialog was used for this step. Over 800 databases were searched via Dialog. Crucial information was also found on web-sites of various companies and organizations. In addition, "primary" sources defined as experts in the field -- were identified and meetings were arranged with them to be held the third week. These meetings were held in Richland, WA where many of the United States' experts of decommissioning and radiological surveying are located. Some specialists were also interviewed over the phone during the technology scanning phase.

\subsection{Analysis}

The third step is the analysis phase. All of the information collected from primary and secondary sources is analyzed during this phase. Criteria are often used to define what information is the most critical and to allow the TSA team to compare and contrast the information. This step is where the team asks the "so what" questions to determine how best to use the information to help the decision maker.

A table matrix was designed to summarize all of the relevant information about the various articles and reports reviewed. In addition, a table was created that describes all of the information about the various experts met (company, title, address, etc., area of expertise and experience). Finally, criteria were developed and used to evaluate instruments. A sample matrix was developed to compare and contrast two instruments. The team identified follow-up work that would be helpful to support making a recommendation to the ChNPP as to which instrument to purchase to support their radiological surveying effort. Information on these two instruments and numerous other instruments was indexed and a presentation describing the results of the TSA project was developed.

\subsection{Delivery and Support for Use}

The fourth step of the TSA process is delivering the results and supporting the client in using the information. To date, a presentation has only been delivered to the experts at Richland, Washington. The plan is to return to Ukraine and present the Team's findings to the managers and staff of the Chornobyl Center and SLIRT. As a follow-up, the TSA team hopes to present the findings to the nuclear regulators of Ukraine and to the decommissioning experts associated with ChNPP.

\subsection{SECONDARY SOURCES}

The Technology Scanning Assessment Process was started with the so called secondary sources which include:

- reference scientific-technical information sources (Dialog); 
- Scientific-technical libraries;

- Web-sites of various companies and organizations producing the appropriate techniques and instruments.

The reason for starting with the secondary sources was their large scope, the time needed to identify, collect, and read all this information, and the need to have this information provide a foundation for interviewing experts (primary sources).

Dialog is a search service for information professionals, offering close to 800 databases on nearly every topic. To effectively work with Dialog a user needs to follow several steps.

In conducting searches for secondary sources, the searcher first needs to develop a list of key words for selecting the necessary information. In our case this list included the following examples:

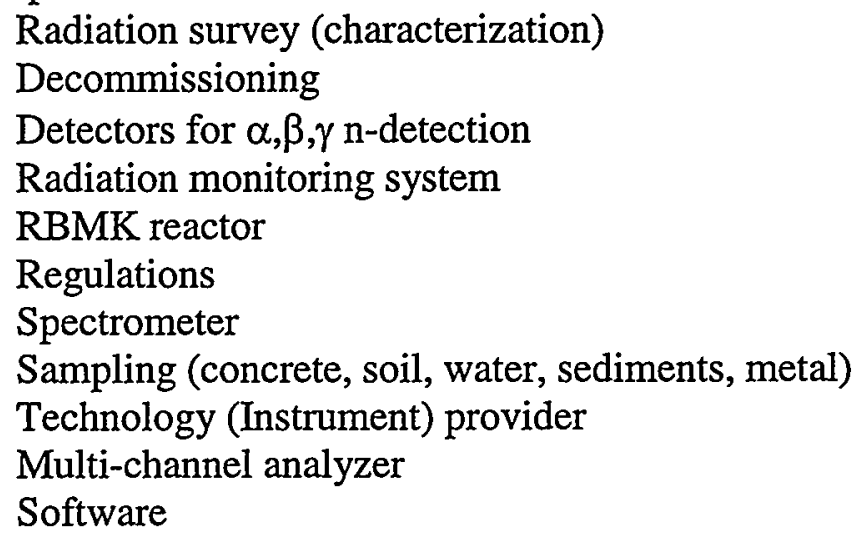

Second, the searcher uses standard selection methods and various combinations of key words to conduct several searches. Three hundred references were found. Third, the search was narrowed to references dated from 1990 to the present, and duplicative references from different databases were removed. The team also reviewed titles and abstracts to identify those references most critical to the project. The team decided to get the full text of about 50 references. Libraries at Battelle Seattle, the University of Washington, and the Hanford Technical Library were used to find these references.

For practice, the team conducted more narrow searches using Dialog, focused on spectrometers. All the references collected were reviewed and summarized in a matrix containing the following fields:

- Objective

- Description

- Time required to take one measurement

- Complexity of the instrument

- Performance

- Cost

- Experience in applying the technology

- Conclusion 
The team wanted to be able to return to this matrix and sort references by whether they focused on regulations, methods, or instruments associated with radiological survey and decommissioning. The matrix is included as Appendix A.

In addition to Dialog, Web-sites of companies and organizations (IAEA, DOE, PNNL, Canberra, BNFL, AIl, etc.) were used. These searches resulted in identifying new references not listed yet in Dialog (e.g., IAEA's report "Radiological Characterization of Shut Down Nuclear Reactors for Decommissioning Purposes," 1998). Specifics about instruments were also found using this technique.

\subsection{PRIMARY SOURCES}

The team's work with primary sources included meeting experts with experience in conducting radiological surveys. While visiting Richland and nuclear facilities under decommissioning at the Hanford site, the team met with experts, engineers, and managers involved in the decommissioning process. They shared with the team their experience in radiological survey planning, sampling, in using special methods and technologies in their activities. They also told the team about the actual decommissioning projects, about the radiochemical laboratories for making sampling analysis, and about different nuclear facilities located at the site.

One PNNL team's experience is mainly with commercial nuclear reactors. This team's sampling and analysis is largely the basis for the U.S. Nuclear Regulatory Commission's rules and regulations for radiological survey requirements prior to decommissioning. This team has experts in the secondary (or auxiliary) parts of reactors and in the primary reactor internals.

Another team, comprised of staff from different organizations at Hanford, has worked extensively on decommissioning Hanford reactors. They provided great practical information on issues to consider in planning and conducting radiological surveys.

Information obtained from these primary sources was of great importance to the team and will contribute greatly to the support the Ukrainian team hopes to provide ChNPP in decommissioning and radiological survey activities.

Teleconferences were also conducted with planning, sampling, technology selection, and radiological survey experts -- another primary information source for the team. Phone conversations with managers, manufacturers, and providers of radiological survey equipment were also important. Table 5.1 is a list of all the primary sources used during the project. 


\section{Table 5.1 Primary Information Sources (continued)}

\section{Table 5.1 Primary Information Sources}

\begin{tabular}{|c|c|c|c|c|c|}
\hline IN & Name & Position & Employees & Phone/Fax & Expertise/ChNPP Relevancy \\
\hline 1. & Abel, Keith H. & $\begin{array}{l}\text { Technical Group Leader, Nuclear } \\
\text { Chemistry Section, MSIN:P8-08, Chemical } \\
\text { Sciences Department }\end{array}$ & PNNL & $\begin{array}{l}\text { T.: (509) 376-8690 } \\
\text { F.: (509) 372-2329 }\end{array}$ & $\begin{array}{l}\text { Characterization of residual } \\
\text { radionuclide contamination of } \\
\text { equipment and materials external } \\
\text { for the reactor at the commercial } \\
\text { plants }\end{array}$ \\
\hline 2. & Cefallo, Grant & Expert in radiological sampling. & BHI & $\begin{array}{l}\text { Tel: (509)-373-6238 } \\
\text { F.:(509) 373-1514 }\end{array}$ & $\begin{array}{l}\text { Provided comparative analysis } \\
\text { of the two types of equipment } \\
\text { RadScan and GammaCam. Also } \\
\text { described ISOCS. Much } \\
\text { knowledge about survey } \\
\text { measurement devices. }\end{array}$ \\
\hline 3. & Day, Dick & $\begin{array}{l}\text { Project Manager for } 105 \mathrm{DR} \\
\text { decommissioning project }\end{array}$ & BHI & $\begin{array}{l}\text { T.(509) 373-7564 } \\
\text { F.(509) } 373-5418\end{array}$ & $\begin{array}{l}\text { Project Manager for } 105 \mathrm{DR} \\
\text { decommissioning project }\end{array}$ \\
\hline 4. & Doran, Nancy & Information Specialist & $\begin{array}{l}\text { Hanford } \\
\text { Technical } \\
\text { Library } \\
\end{array}$ & $\begin{array}{l}\text { T.(509) } 372-7434 \\
\text { F.: (509) } 372-7431\end{array}$ & $\begin{array}{l}\text { Can provide assistance in } \\
\text { searching for references }\end{array}$ \\
\hline 5. & Glukhov, Andrei Y. & Project Manager, INSP & Battelle & $\begin{array}{l}\text { T.: (509) 375-3961 } \\
\text { F.: (509) 372-4411 } \\
\text { E-m.:ay_glukhov@ccmail.pnl.gov }\end{array}$ & $\begin{array}{l}\text { Satellite communications, NDB } \\
\text { projects }\end{array}$ \\
\hline 6. & Hamblin, Steve & & $\overline{\text { BHI }}$ & $\begin{array}{l}\text { T.(509) } 372-0491 \\
\text { F.(509) } 373-1022\end{array}$ & $\begin{array}{l}105 \mathrm{DR} \text { decommissioning } \\
\text { project implementation }\end{array}$ \\
\hline 7. & Koegler, Kim & Technology Application & $\begin{array}{l}\text { Bechtel } \\
\text { Hanford, Inc. }\end{array}$ & $\begin{array}{l}\text { T.: (509) 372-9294 } \\
\text { F.: (509) 372-9718 } \\
\text { E-m.: kikocgle@bhi-crc.com }\end{array}$ & $\begin{array}{l}\text { Technology scanning practical } \\
\text { results. Approaches from } \\
\text { working on Hanford C Reactor. }\end{array}$ \\
\hline 8. & Kreid, Dennis K. & $\begin{array}{l}\text { Manager, Hanford Chernobyl Shelter } \\
\text { Project, INSP }\end{array}$ & PNNL & $\begin{array}{l}\text { T.: (509) 375-2170 } \\
\text { F.: (509) 375-2203 } \\
\text { E-m.:dk.kreid@pnl.gov }\end{array}$ & $\begin{array}{l}\text { Chornobyl projects contact } \\
\text { person. Project Manager for } \\
\text { Shelter. Other projects including } \\
\text { decommissioning. Supporting } \\
\text { privatization activities too. }\end{array}$ \\
\hline
\end{tabular}


Table 5.1 Primary Information Sources (continued)

\begin{tabular}{|c|c|c|c|c|c|}
\hline IN & Name & Position & Employees & Phone/Fax & Expertise/ChNPP Relevancy \\
\hline 9. & Lepel, Elwood A. & $\begin{array}{l}\text { Senior Research Associate Radiological \& } \\
\text { Chemical Sciences Group, National } \\
\text { Security Division, MSIN:P8-08 }\end{array}$ & 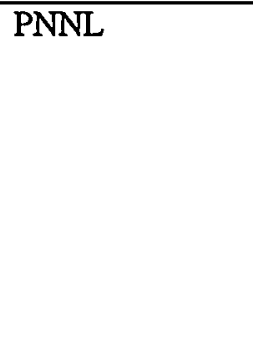 & $\begin{array}{l}\text { T.: (509) 376-3390 } \\
\text { F.: (509) 372-0672 } \\
\text { E-m.:ea.lepel@pnl.gov }\end{array}$ & $\begin{array}{l}\text { Can provide assistance in } \\
\text { selecting the appropriate } \\
\text { methods, techniques and } \\
\text { instruments for radiological } \\
\text { survey. Characterization of long- } \\
\text { lived activated products in metal } \\
\text { and reactor components (spent } \\
\text { fuel assemblies, spent control } \\
\text { rods) }\end{array}$ \\
\hline 10. & Marske, Steven G. & Project Manager & $\begin{array}{l}\text { CH2M Hill } \\
\text { Hanford, Inc. }\end{array}$ & $\begin{array}{l}\text { T.: (509) 373-4316 } \\
\text { F.: (509) 373-5470 } \\
\text { E-m.:sgmarske@bhi-erc.com }\end{array}$ & $\begin{array}{l}\text { Designs in radiological survey } \\
\text { process prior to } \\
\text { decommissioning (planning, } \\
\text { sampling, instruments for } \\
\text { surveying process) }\end{array}$ \\
\hline 11. & Mihalic, Michael & Manager & BHI & $\begin{array}{l}\text { T.: (509)373-1382 } \\
\text { F.(509)373-5418 }\end{array}$ & $\begin{array}{l}\text { Manages decommissioning } \\
\text { effort at } 105 \mathrm{DR}\end{array}$ \\
\hline 12. & Morton, Mark & & BHI & $\begin{array}{l}\text { T.:(509) 373-9618 } \\
\text { F.:(509) 372-9654 }\end{array}$ & $\begin{array}{l}\text { At ChNPP, Comprehensive } \\
\text { Engineering Radiation Plan } \\
\text { support, and other D\&D support. }\end{array}$ \\
\hline 13. & $\begin{array}{l}\text { Reed, Steve } \\
\end{array}$ & & $\begin{array}{l}\text { Thermo } \\
\text { Hanford Inc. }\end{array}$ & $\begin{array}{l}\text { T.:(509) 531-0747 } \\
\text { F.:(509) 373-1022 }\end{array}$ & $\begin{array}{l}\text { Radiological Engineer working } \\
\text { on } 105 \text { DR reactor at Hanford. } \\
\text { Work used in developing } \\
\text { NUREGs and regulations }\end{array}$ \\
\hline 14. & Robertson, David E. & $\begin{array}{l}\text { Manager, Radiological and Chemical } \\
\text { Sciences Group, National Security Division, } \\
\text { MSIN:P8-20 }\end{array}$ & PNNL & $\begin{array}{l}\text { T.: (509) 376-5664 } \\
\text { F.: (509) 376-3868 } \\
\text { E-m.dde robertson@pnl.gov }\end{array}$ & $\begin{array}{l}\text { Direct radiological survey } \\
\text { analysis of commercial plants } \\
\text { prior to decommissioning. }\end{array}$ \\
\hline 15. & Sande, Susan & Business Information Specialist & $\begin{array}{l}\text { Washington } \\
\text { State University } \\
\text { (Library) }\end{array}$ & $\begin{array}{l}\text { T.: (509) 372-7621 } \\
\text { F.: (509) 372-7512 } \\
\text { E-m.bic@triity.wsu.edu }\end{array}$ & $\begin{array}{l}\text { General information about how } \\
\text { one can access information on } \\
\text { businesses. }\end{array}$ \\
\hline 16. & Steve Short & DD\&D Project Manager & PNNL & Steve.short@pnl.gov & $\begin{array}{l}\text { General approaches to the D\&D } \\
\text { activities at the ChNPP. } \\
\text { Information about the current } \\
\text { status of the ChNPP D\&D } \\
\text { project. }\end{array}$ \\
\hline
\end{tabular}


Table 5.1 Primary Information Sources (continued)

\begin{tabular}{|c|c|c|c|c|c|}
\hline $\mathbf{I N}$ & Name & Position & Employees & Phone/Fax & Expertise/ChNPP Relevancy \\
\hline 17. & Smith, Kris A. & Operations Manager & $\begin{array}{l}\text { Thermo } \\
\text { Hanford Inc. (A } \\
\text { Thermo Retec } \\
\text { Company) }\end{array}$ & $\begin{array}{l}\text { T.: (509) 373-9702 } \\
\text { F.: (509) 372-9448 } \\
\text { E-m.:kasmith @bhi-erc.com }\end{array}$ & $\begin{array}{l}\text { LARAD (Laser Assisted } \\
\text { Ranging and Data). } \\
\text { Demonstrated at Hanford C } \\
\text { Reactor. Has much hands-on } \\
\text { experience with } \\
\text { decommissioning. }\end{array}$ \\
\hline 18. & St.John, Dave & Radiation Sampling Expert & $\overline{\mathrm{BHI}}$ & $\begin{array}{l}\text { T.:(509) 372-9588 } \\
\text { F.:(509) 372-9487 }\end{array}$ & $\begin{array}{l}\text { Told about DQO, S\&A } \\
\text { Planning, structure of the } \\
\text { sampling group, rules and } \\
\text { training for the sampling group } \\
\text { staff. }\end{array}$ \\
\hline 19. & Tavares, Claudia C. & Information Specialist & $\begin{array}{l}\text { Hanford } \\
\text { Technical } \\
\text { Library, } \\
\text { MSIN:P8-55 }\end{array}$ & $\begin{array}{l}\text { T.: (509) 372-7451 } \\
\text { F.: (509) 372-7431 } \\
\text { E-m.:claudia.tavares@pnl.gov }\end{array}$ & Patent searching specialist \\
\hline 20. & Wood, Thomas W. & $\begin{array}{l}\text { Manager, Engineering Performance \& Risk } \\
\text { Analysis Group, } \\
\text { Environmental Technology Division }\end{array}$ & Battelle, PNNL & $\begin{array}{l}\text { T.: (509) 372-4162 } \\
\text { F.: (509) 375-5921 } \\
\text { E-m.:thomas.wood@pnl.gov }\end{array}$ & $\begin{array}{l}\text { Radiation Survey, D\&D } \\
\text { activities. }\end{array}$ \\
\hline
\end{tabular}




\subsection{ANALYSIS}

The third stage of the TSA process is the analysis of the data obtained both from secondary (Dialog, web-sites, libraries) and primary (experts interviewed, visiting facilities under decommissioning) sources.

The four main goals of the available data analysis are:

- To define a general approach to decommissioning, with an emphasis on conducting radiological surveys based on regulations, guides, procedures and manuals applied in different countries.

- To identify radiological survey technology needs.

- To define criteria for selecting the appropriate technology, based on the data obtained from both types of sources.

- To identify technology types and examples of specific instruments to meet the needs.

\subsection{Regulations, Guidelines, and Methods}

Several sources were used in gathering information on how to frame a decommissioning process. Code and Federal Regulations, guidelines, and manuals that describe the basic nuclear facility decommissioning processes were used, as well as information from engineers, experts, and managers participating in this process. Based on this information, the team developed a general approach for decommissioning, and in particular for conducting a radiological survey prior to decommissioning.

\subsubsection{Decommissioning Overview}

For nuclear facilities, decommissioning is the final phase in the life-cycle after siting, design, construction, commissioning and operation. It is a complex process involving activities such as decontamination, dismantling and demolition of equipment and structures, and management of resulting waste, while taking into account aspects of health and safety of the operating personnel and the general public, as well as protection of the environment. The ultimate objective of decommissioning is unrestricted release or reuse of the site. Figure 6.1 is a flow diagram of the decommissioning process. 


\section{Figure 6.1 General Decommissioning Process}

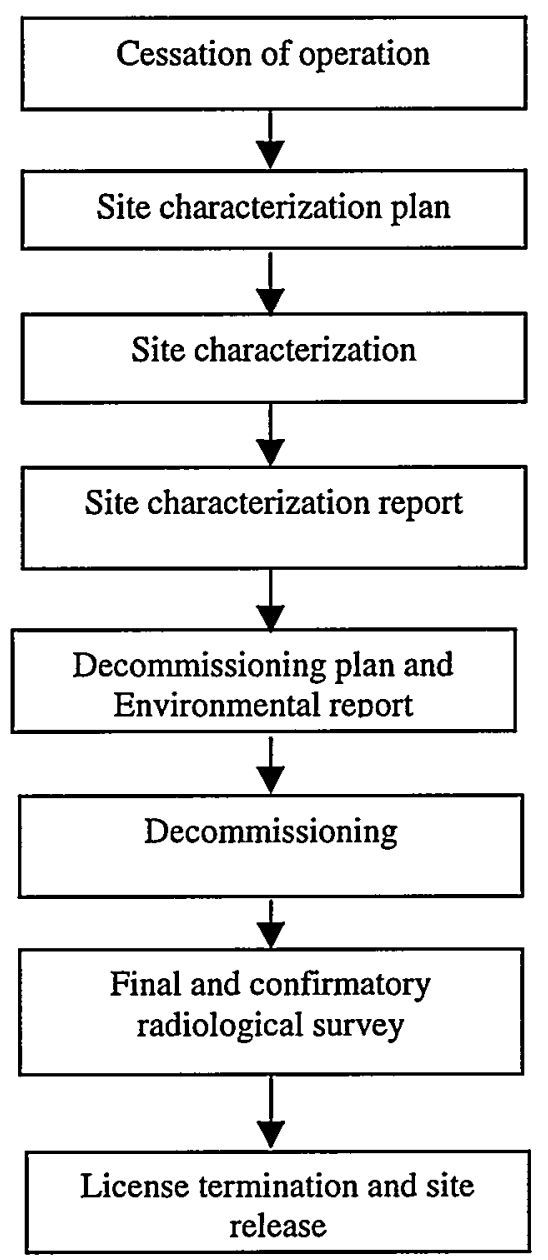

The decommissioning strategy for nuclear reactors can vary from case to case. It typically ranges from immediate dismantling to postponed dismantling after a safe enclosure period. The strategy for dismantling depends on many factors, such as:

- national policy;

- availability of waste routes;

- occupational, public and environmental safety;

- skill resources;

- cost considerations, including availability of funding;

- structural deterioration;

- interdependence with other on-site activities

\subsubsection{Objective of Characterization}

Characterization is an initial step in the decommissioning process and requires a logical approach to obtain the data necessary for planning a decommissioning program. The objective of characterization is to provide a reliable database of information on quantity and type of radionuclides, their distribution, and their physical and chemical states.

Characterization involves a survey of existing data, calculations, in situ measurements, 
and/or sampling and analyses. Using the database, the decommissioning planner may assess various options and their consequences, considering:

- operating techniques: decontamination processes, dismantling procedures (hands on, semi-remote, or fully remote working) and tools required;

- protection of workers, general public and environment;

- waste classification;

- resulting costs.

Comparison and optimization of these factors will lead to selecting a decommissioning strategy, i.e. typically, immediate or deferred dismantling. It should be noted that the characterization process is sequential in that further steps can be decided only after the results of previous characterization steps have become available.

\subsubsection{Radiological Characterization Process}

The characterization process includes gathering radiological information on the shut down reactor, which enables decisions on other decommissioning steps such as decontamination, dismantling and removal of components and equipment, demolition of structures, management of decommissioning waste, estimates of future radionuclide inventories and the funding of decommissioning activities. A comprehensive characterization program is comprised of the following steps as in Figure 6.2:

\section{Figure 6.2 Radiological Characterization Process}

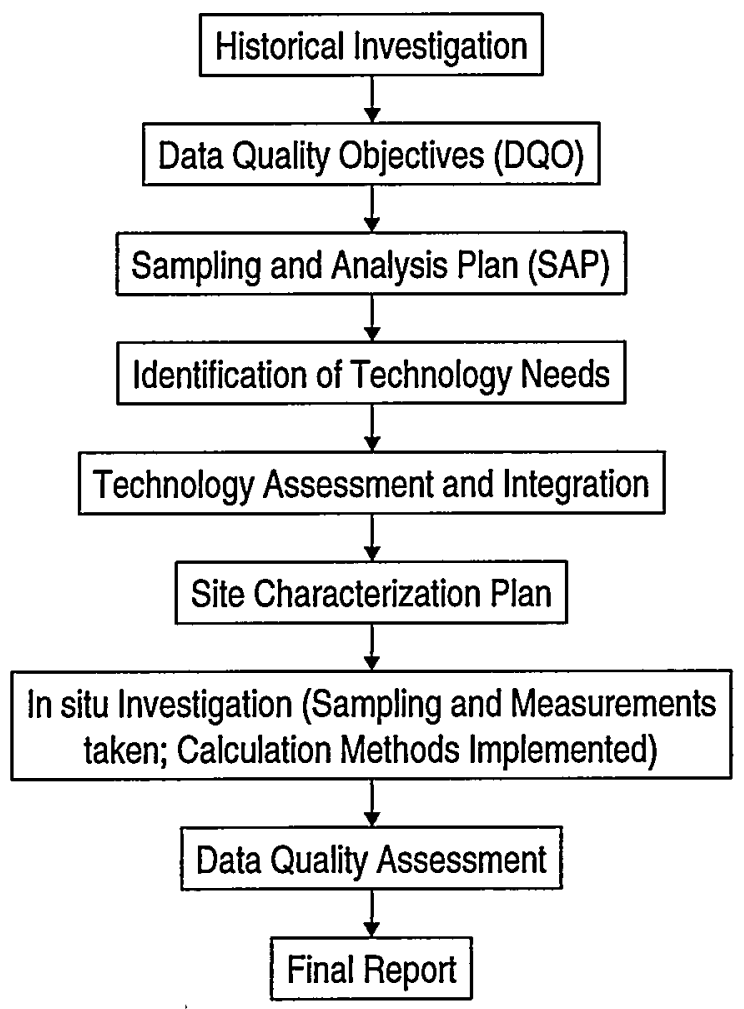


The following sections expand on each of these steps in the context of the radiological component of characterization. Listed below are the critical regulations, guidance, and manuals used to define and describe these steps.

- 10 CFR 30.36, 50.42, 50.82, 70.38, and 72.54. U.S. Nuclear Regulatory Commission

- Standard Guide for Selection and Use of Portable Radiological Survey Instruments for Performing In Situ Radiological Assessment in Support of Decommissioning 1998 (ASTM Designation: E1893-97)

- Multi-Agency Radiation Survey and Site Investigation Manual (MARSSIM), 1997 E1893-97 (NUREG-1575)

- Manual for Conducting Radiological Surveys in Support of License Termination, 1992 (NUREG/CR-5849)

- Radionuclide Characterization of Reactor Decommissioning Waste and Neutron Activated Metals, 1993 (NUREG/CR-5894)

- Residual Contamination Within and Around Commercial Nuclear Power Plants, 1986 (NUREG/CR-4289)

- Radiological Characterization of Shut Down Nuclear Reactors for Decommissioning Purposes. IAEA, Technical Report Series No. 389, 1998.

\subsubsection{Historical Investigation}

Reviewing historical information about a reactor provides the decommissioning planner with valuable knowledge of possible radiological conditions present. This information may consist of records or recollections of contamination spills or other unusual events, and/or previous surveys and measurements. Important in this context are the records of occupational exposures incurred during inspection, survey, maintenance, and repair activities. Occupational exposures incurred during replacement of major contaminated components are practically relevant. In addition, by identifying the list of possible contaminants from a review of reactor history, one can optimize the characterization effort and avoid spending time, money, and unnecessary exposure of workers trying to measure something known not to be present. It should also be noted that the structural condition of the facility is important, particularly in the case of deferred dismantling, and structural surveys must be carried out in addition to radiological characterization. Particularly important are as-built drawings including the materials used, and modifications of structures and equipment in restricted areas where radioactive materials are processed or stored, and of locations of possible inaccessible contamination.

Information on process upsets or unusual events that might have spread contamination to unexpected areas is particularly important. Another type of historical information is the result of previous surveys and measurements.

Routine radiation survey and surveys conducted to support special work are both useful. The information they provide may be sufficient to actually replace characterization or, at the very least, may allow a more efficient characterization plan to be designed. 


\subsubsection{Data Quality Objectives (DQO)}

The first step in designing effective surveys is planning. The DQO Process is a number of planning steps based on the scientific method for establishing criteria for data quality and developing survey design. Planning radiation surveys using the DQO Process improves the survey effectiveness and efficiency, and thereby the defensibility of decisions. This minimizes expenditures related to data collection by eliminating unnecessary or duplicative data. Using the DQO process ensures that the type, quantity, and quality of environmental data used in decision making will be appropriate for the intended application.

The DQO process provides systematic procedures for defining the criteria that the survey design should satisfy, including what type of measurements should be performed, when and where to perform the measurements, the level of decision errors for the survey, and how many measurements to perform.

DQOs are qualitative and quantitative statements derived from the outputs of the DQO Process that:

- Clarify the study objective;

- Define the most appropriate type of data to collect;

- Determine the most appropriate conditions for collecting the data;

- Specify limits on decision error that will be used as the basis for establishing the quantity and quality of data needed to support the decision.

The DQO Process consists of seven steps: ${ }^{1}$

\section{Step 1: State the Problem}

Concisely describe the problem to be studied. Review prior studies and existing information to gain a sufficient understanding to define the problem.

\section{Step 2: Identify the Decision}

Identify what questions the study will attempt to resolve, and what actions may result.

\section{Step 3: Identify the Inputs to the Decision}

Identify the information that needs to be obtained and the measurements that need to be taken to resolve the decision statement.

\section{Step 4: Define the Study Boundaries}

Specify the time periods and spatial area to which decisions will apply.

Determine when and where data should be collected.

\footnotetext{
${ }^{1}$ Reference: "Guidance for the Data Quality Objective Process," EPA QA/G-4, September 1994.
} 


\section{Step 5: Develop a Decision Rule}

Define the statistical parameter of interest, specify the action level, and integrate the previous DQO outputs into a single statement that describes the logical basis for choosing among alternative actions.

\section{Step 6: Specify Tolerable Limits on Decision Errors}

Define the decision maker's tolerable decision error rates based on a consideration of the consequences of making an incorrect decision.

\section{Step 7: Optimize the Design}

Evaluate information from the previous steps and generate alternative data collection designs. Choose the most resource-effective design that meets all DQOs.

\subsubsection{Sampling and Analysis Plan (SAP)}

The decision maker and the survey planning team need to identify the data needs for the survey being performed, including the:

- Type of samples to be collected or measurements to be performed

- Radionuclides of interest

- Number of samples to be collected

- Type and frequency of field samples to be collected

- Amount of material to be collected for each sample

- Sampling locations and frequencies

- Standard operating procedures to be followed or developed

- Analytical bias and precision (e.g., quantitative or qualitative)

- Target detection limits for each radionuclide of interest

- Cost of the methods being evaluated (cost per analysis as well as total cost)

- Necessary turnaround time

- Sample preservation and shipping requirements

- Specific background for the radionuclides of interest

- Derived concentration guideline level for each radionuclides of interest

- Measurement documentation requirements

- Sample tracking requirements

Some of this information will be supplied by subsequent steps in the DQO process; several iterations of the process may be needed to identify all of the data needs. Consulting with a radiochemist may be necessary to properly evaluate the information before deciding between direct measurements or sampling methods to perform during the survey.

The radioanalytical laboratory is a valuable resource during survey planning. Information on available analytical techniques, analytical bias and precision, methods detection limits, analytical costs, and turnaround times can easily be provided by the laboratory. Additional information such as required sample size/volume, type of sample container, preservative requirements and shipping requirements can be obtained and factored into the survey plan. 


\subsubsection{Technology Assessment and Integration}

Having identified the DQOs and developed a detailed SAP, the project managers need to identify the technology needs for implementing the SAP. In some cases, technologies already owned may be sufficient, and in other cases technologies may need to be purchased. In still other cases, new technologies under development may be of interest. At this stage a list of technology needs is developed.

A working group of experts, engineers, and consultants may contribute to identifying the technology needs. The purpose of technology assessment is to analyze a set of technologies and instruments able to assist the project and then to identify and recommend for future use the most acceptable ones for radiological characterization.

The Technology Assessment and Integration process consists of the following steps:

- Develop criteria to evaluate technology;

- Develop weighting process for applying criteria

- Conduct technology assessment

- Recommend technology

- Support technology performance

Under the TSA project, the team searched information about technologies and instruments for radiological characterization from both secondary and primary sources, analyzed the information, and developed recommendations for using the information, technologies, and instruments.

\subsubsection{Characterization Survey}

A characterization survey is based on a characterization plan that includes information from the historical assessment, DQO, SAP, and technologies selected from the Technology Assessment and Integration step. In situ investigations include physical, chemical, and radiological investigations. Radiological investigations include direct measurements, scanning measurements, sampling using laboratory analysis (on-site or off-site), and calculation methods. ${ }^{2}$

Radiological characterization for decommissioning should be based on a detailed, actual sampling, and analysis for determining residual radioactivity. Much of the following description of survey design comes from personal communications with David Robertson and his team members (Keith Abeland and Elwood Lepel) from PNNL (March 15, 1999).

As part of the survey, all contaminated/activated (and potentially contaminated) equipment, facilities and environs should be examined. Neutron-activated materials, as well as contamination spread through reactor coolant/steam and auxiliary plant systems

\footnotetext{
${ }^{2}$ Charles Thomas from PNNL provided the team with actual concentrations of trace elements in graphite taken from two different reactors (U.S.-Hanford, and French). See Appendix B for tables describing the results of this work. Both destructive and non-destructive radiochemical analyses were used. This information is included as an example.
} 
should be included. Characterization may be expedited by applying the use of activity scaling (correlation) factors.

The scaling factor (radionuclide ratios) approach includes conducting a detailed sampling and radiochemical analysis of all main plant systems for all potentially significant longlived radionuclides:

$\begin{array}{llllll}\text { H-3 } & \text { Be-10 } & \text { C-14 } & \text { Cl-36 } & \text { Co-60 } & \\ \text { Ni-59-63 } & \text { Sr-90 } & \text { Mo-93 } & \text { Nb-93m-94 } & \text { Tc-99 } & \\ \text { Cs-137 } & \text { Pu } & \text { Ag-108m } & \text { I-129 } & \text { Am } & \text { Cm }\end{array}$

Next, a plant database of activity scaling factors (radionuclide ratios) of non-gammaemitting radionuclides to easily-measurable gamma-emitting radionuclides (i.e. Ni63/Co-60, Mo-93/Co-60, Sr-90/Cs-137, Tc-99/Co-60, I-129/Cs-137) should be developed.

Subsequent radiological characterization can be done by direct gamma-ray spectrometry and application of activity scaling factors. In addition, dose-to-activity measurements can expedite radiological surveys.

\subsubsection{Data Quality Assessment}

A Data Quality Assessment (DQA) is a scientific and statistical evaluation that determines if the data are of the right type, quality, and quantity to support their intended use. There are five steps in the DQA process:

- Review the Data Quality Objectives and Survey Design;

- Conduct a preliminary data review;

- Apply the statistical test;

- Verify the assumptions of the statistical test;

- Make conclusions from the data.

The strength of the DQA process is that it is designed to promote an understanding of how well the data met their intended use by progressing in a logical and efficient manner.

\subsubsection{Radiation Characterization Final Report}

The Radiation Characterization Final Report includes information important for future actions in decommissioning planning. The main items of the report are:

- Background;

- Site description;

- Operating history;

- Limits and conditions for the shutdown reactor;

- Survey techniques;

- Survey findings;

- Summary 
A large quantity of data may be generated during characterization activities. For orderly decommissioning planning, it is important that all information generated during the decommissioning characterization process be available in a well-documented form. It has to be recognized that adequate record-keeping plays an important role in the overall decommissioning process. To enable careful planning of the work to be done in a hostile environment, it is not only necessary to collect and periodically update information relevant to the plant design but also to gather adequate information concerning the unit's operating performance, especially on non-routine occurrences such as spills. Considering the great number of components within a reactor plant, the development of a computerized database can facilitate the problem of storing and updating all the necessary information.

It is recommended that a report summarizing the characterization process and the data collected be prepared by plant personnel who have appropriate experience. The information contained in the report will be used to guide the decommissioning planning.

\subsection{Technology Needs Identified for Radiological Surveying}

The purpose of the radiological survey is to compile a detailed picture of the radiological contamination condition at the nuclear power plant (NPP) that is to be decommissioned. A recent IAEA report (1998) summarizes the types of data needs an NPP has for surveying radiological contamination. Table 6.3 lists these types of data needs, specific uses of the data, and data collection methods that it recommends considering.

Technologies are necessary for each of the data collection methods. In some cases a technology appropriate to addressing one need can be applicable to addressing another need. As mentioned earlier, direct measurements, scanning measurements, and sampling techniques are all necessary and used during radiological surveying prior to decommissioning.

The focus of the TSA project is on in-situ direct measurements and in-situ scanning measurements, not on laboratory analysis. The latter is critical but the decision was to focus the project on in-situ measurement techniques. Appendix $\mathrm{C}$ includes tables describing specifics about different types of radiation detectors with applications to gamma and $\mathrm{x}$-ray surveys, alpha surveys, and beta surveys. A table from the MultiAgency Radiation Survey and Site Investigation Manual (MARSSIM) (NUREG-1575, 1997) gives an overview of the type of detectors for each type of radiation emitter (e.g., alpha) and then more detailed tables follow from MARSSIM for each type of radiation emitter including information about full systems and approximate prices. 
Table 6.3 Radionuclide Inventory Data Needs, Uses, and Collection Methods

\begin{tabular}{|l|l|l|}
\hline \multicolumn{1}{|c|}{ Data needs } & \multicolumn{1}{|c|}{ Specific uses of data } & Data collection methods \\
\hline $\begin{array}{l}\text { 1. Radiation }(\alpha, \beta, \gamma) \text { dose } \\
\text { or exposure rates }\end{array}$ & $\begin{array}{l}\text { Necessary to identify } \\
\text { radiation hazards and access } \\
\text { limitations, to specify } \\
\text { decommissioning } \\
\text { procedures and methods, } \\
\text { and to estimate waste } \\
\text { volumes }\end{array}$ & $\begin{array}{l}\text { Direct radiation } \\
\text { measurements, screening } \\
\text { level, air monitoring }\end{array}$ \\
\hline $\begin{array}{l}\text { 2. Amount of loose and } \\
\text { fixed contamination on } \\
\text { surfaces }\end{array}$ & $\begin{array}{l}\text { Necessary to evaluate } \\
\text { effectiveness of pre- } \\
\text { decontamination, to plan } \\
\text { protection against airborne } \\
\text { releases and to identify } \\
\text { personnel protection } \\
\text { measures }\end{array}$ & $\begin{array}{l}\text { Analyses of smear samples } \\
\text { and correlated radiation } \\
\text { measurements }\end{array}$ \\
\hline $\begin{array}{l}\text { 3. Location of radiation } \\
\text { sources and } \\
\text { contamination 'hot } \\
\text { spots' }\end{array}$ & $\begin{array}{l}\text { Necessary to evaluate } \\
\text { design sequence of } \\
\text { decommissioning actions, } \\
\text { to specify decommissioning } \\
\text { procedures and methods }\end{array}$ & $\begin{array}{l}\text { Direct radiation scans, } \\
\text { process }\end{array}$ \\
\hline $\begin{array}{l}\text { 4. Contaminant } \\
\text { penetration into walls } \\
\text { and floors }\end{array}$ & $\begin{array}{l}\text { Necessary to design } \\
\text { sequence of } \\
\text { decommissioning actions, } \\
\text { to specify decommissioning } \\
\text { procedures and methods }\end{array}$ & $\begin{array}{l}\text { Scans and analyses of core } \\
\text { samples }\end{array}$ \\
\hline $\begin{array}{l}\text { 5. Contamination levels in } \\
\text { soils under and near the } \\
\text { facility }\end{array}$ & $\begin{array}{l}\text { Necessary to specify } \\
\text { decommissioning } \\
\text { procedures and methods, to } \\
\text { assess foundation removal } \\
\text { and excavation hazards }\end{array}$ & $\begin{array}{l}\text { Analyses of soil samples, } \\
\text { historical soil and sampling } \\
\text { data }\end{array}$ \\
\hline
\end{tabular}

(Source: IAEA Report No. 389/1998)

\subsubsection{Scanning Measurement Techniques}

Scanning measurement (surveys) is the process by which the operator uses portable radiation detection instruments to identify the presence of radionuclides on a specific surface (i.e., ground, wall, floor, equipment). The term scanning survey is used to describe the process of moving portable radiation detectors across a surface suspected to be contaminated. The intent is to locate the area and type of contamination. Scanning surveys are performed to locate radiation anomalies indicating residual gross activity that may require further investigation or action. 
Small areas of elevated activity can be difficult to find using only direct measurements or sampling techniques. Scanning surveys are necessary to find such radiation. These surveys are often relatively quick and inexpensive to perform. For these reasons, scanning surveys are typically performed before direct measurements or sampling. Scanning surveys are conducted to determine which radionuclides are potentially present.

The following sections briefly describe techniques used to perform scanning surveys for different types of radiation.

\subsubsection{Scanning for Photon Emitting Radionuclides}

Sodium iodide survey meters (NaI (TI) detectors) are normally used for scanning areas for gamma emitters because they are very sensitive to gamma radiation, easily portable, and relatively inexpensive. The detector is held close to the ground surface $(\sim 6 \mathrm{~cm}$ or $2.5 \mathrm{in}$.) and moved in a serpentine (i.e. snake like, "S" shaped) pattern while walking at a speed that allows the investigator to detect the desired investigation level.

Sodium iodide survey meters are also used for scanning to detect areas with elevated areas of low-energy gamma and $\mathrm{x}$-ray emitting radionuclides such as ${ }^{241} \mathrm{Am}$ and ${ }^{239} \mathrm{Pu}$. Specially designed detectors, such as the FIDLER (field instrument for the detection of low energy radiation) probe with survey meter, are typically used to detect these types of radionuclides.

\subsubsection{Scanning for Alpha Emitting Radionuclides}

Alpha scintillation survey meters and thin window gas-flow proportional counters are typically used for performing alpha surveys. Alpha radiation has a very limited range and therefore, instrumentation must be kept close to the surface - usually less than $1 \mathrm{~cm}$ (0.4 in.). For this reason, alpha scans are generally performed on relatively smooth, impermeable surfaces (e.g. concrete, metal, drywall) and not on porous material (e.g. wood) or for volumetric contamination (e.g. soil, water).

\subsubsection{Scanning for Beta Emitting Radionuclides}

Thin window gas-flow proportional counters are normally used when surveying for beta emitters, although solid scintillators designed for this purpose are also available. Typically, the beta detector is held less than $2 \mathrm{~cm}$ from the surface and moved at a rate such that the desired investigation level can be detected. Low-energy $(<100 \mathrm{keV})$ beta emitters are subject to the same interferences and self-absorption problems found with alpha emitting radionuclides, and scans for these radionuclides are performed under similar circumstances.

\subsubsection{Direct Measurement Techniques}

To conduct direct measurements of alpha, beta, and photon surface activity, instruments and techniques providing the required detection sensitivity are selected. The type of instrument and method of performing the direct measurement are selected as dictated by 
the type of potential contamination present, the measurement sensitivity requirements, and the objectives of the radiological survey. Direct measurements are taken by placing the instrument at the appropriate distance above the surface, taking a discrete measurement for a pre-determined time interval (e.g., 10 seconds, 60 seconds), and recording the reading. A one minute integrated count technique is a practical field survey procedure for most equipment and provides detection sensitivities that are below most derived concentration guideline levels. However, longer or shorter integrating times may be warranted.

Direct measurements may be collected at random locations in the survey unit. Alternatively, direct measurements may be collected at systematic locations and supplemented with scanning surveys to identify small areas of elevated activity. Direct measurements may also be collected at locations identified by scanning surveys as part of an investigation to determine the source of the elevated instrument response. All direct measurement locations and results should be documented.

The following sections briefly describe methods and instruments used to perform direct measurements in the field.

\subsubsection{Direct Measurements for Photon Emitting Radionuclides}

There are a wide variety of instruments available for measuring photons in the field but all of them are used essentially the same way. The detector is set up at a specified distance from the surface being measured and data are collected for a specified period of time.

Example:

A portable detector, or in situ gamma spectrometer, can be used to estimate gammaemitting radionuclide concentrations in the field. As with the laboratory-based germanium detector with multi-channel analyzer, in situ gamma spectrometry can discriminate among various radionuclides on the basis of characteristic gamma and $\mathrm{x}$-ray energies to provide a nuclide-specific measurement.

\subsubsection{Direct Measurements for Alpha Emitting Radionuclides}

Direct measurements for alpha-emitting radionuclides are generally performed by placing the detector on or near the surface to be measured. The limited range of alpha particles (e.g., about $1 \mathrm{~cm}$ or $0.4 \mathrm{in}$. in air, less in denser material) means that these measurements are generally restricted to relatively smooth, impermeable surfaces such as concrete, metal or drywall where the activity is present as surface contamination. In most cases, direct measurement of porous (e.g., wood) and volumetric (e.g., soil, water) material cannot meet the objectives of the survey. However, special instruments such as the longrange alpha detector have been developed to measure the concentration of alpha emitting radionuclides in soil under certain conditions. Because the detector is used in close proximity to the potentially contaminated surface, contamination of the detector or damage to the detector caused by irregular surfaces need to be considered before performing direct measurements for alpha emitters. 


\subsubsection{Direct Measurements for Beta Emitting Radionuclides}

Direct measurements for beta emitting radionuclides are generally performed by placing the detector on or near the surface to be measured, similar to measurements for alpha emitting radionuclides. Special instruments such as large area gas-flow proportional counters and arrays of beta scintillators have been developed to measure the concentration of beta emitting radionuclides.

\subsection{Technology Selection Criteria}

Several sources were used in developing criteria to evaluate and select technologies. During the Needs Assessment step, experts were asked to explain what information they would like to have about technologies to help them decide which ones to purchase for radiological surveying. This information was structured into criteria included in the TSA Work Plan (Appendix D). Criteria were also looked for in articles read during the Technology Scanning step. Finally, experts (primary sources) were interviewed as part of the Technology Scanning step and asked to provide the team with a list of criteria they use to evaluate and select technologies. The result is the following list of criteria and associated definitions.

1. Performance

- Sensitivity

- Accuracy

- Other characteristics specific for this very instrument.

2. Limitation/Utility Requirements

3. Experience of applying

4. Cost/Delivery Support

The definitions of these criteria and subcriteria largely come from Bechtel Hanford's work at $C$ Reactor. Bechtel used these criteria to select specific radiological survey technologies to demonstrate. The definitions follow.

\subsubsection{Performance}

This is the most important criterion for comparing the technical components of instruments and products.

Performance includes the subcriteria:

- Accuracy

It is the most important criterion for the detection of environmental contaminants in any environmental media. This criterion includes ensuring the quality of the data.

- Sensitivity

Sensitivity of a characterization instrument is important for detecting and quantifying contaminants. Higher sensitivity helps to provide accurate data and meet stringent regulatory standards (e.g., waste handling and disposal criteria). 
- Other characteristics specific for each separate instrument, such as:

Efficiency

Dynamic range

Angle of view

\subsubsection{Limitations/Utility Requirements}

These characteristics were analyzed together because both of them either lead to limitations in instrument operation or describe some specific operational requirement.

Limitations can apply to the types of waste forms and types of contaminants for which an instrument is suitable. Also, operational flexibility in collecting data is important. The team included ease of use under this criterion. Is the instrument awkward to use, heavy, easy to learn how to use (skill-level required)? Other descriptions (which can be limitations of an instrument) include:

- dust content

- temperature

- humidity

- vibration

- pressure

- etc.

Utility requirements are often associated with the instrument power supply:

- line-operated

- portable using batteries

- cooling requirements (GE detectors)

\subsubsection{Experience of Applying}

Technologies with a strong experience base are important. The team looked at operational experience and spoke with users of technologies to gain first-hand knowledge about their capabilities. In some cases new technologies may be of interest but the focus of our project was on commercially-available technologies.

\subsubsection{Cost/Delivery Support}

Cost is always of great importance if not the most important criterion following health and safety. The possible options of not only purchasing the equipment but also of renting it were analyzed. The possibility of purchasing the equipment from local Ukrainian manufacturers was also considered.

Delivery includes:

- terms of delivery

- existing of manufacturer's office in Ukraine or Eastern Europe 
Support includes:

- warranty service

- after-warranty service

Y2K issues

\subsubsection{Applying the Criteria}

A matrix was developed with these fields to help evaluate the technologies. A final field to the matrix was added called Advantages/Disadvantages to summarize the strengths and weaknesses of a particular technology. This field summarizes the critical information provided in the previous criteria as well as some additional information. The following items were regarded as disadvantages:

- Risks/hazards

- Characterization technologies are often associated with risks/hazards in terms of field implementation, monitoring, and calibration.

- Waste generation

\subsection{Technology Scanning Analysis: An Example}

Primary and secondary sources that identified manufacturers of radiological survey instruments products were used. Nuclear Plant Journal was the main secondary source; it contains listing of companies that manufacture various equipment in support of nuclear power plants. The information in this magazine was analyzed with the help of primary sources. Dave Robertson's group at PNNL (Keith H. Abel and Elwood A. Lepel) used the magazine as a source to develop a list of the companies they felt represent the greatest capability in the technology need areas (See Table 6.4).

Other sources were used for identifying manufacturers and products. Grant Cefallo from Bechtel Hanford provided great insights based on his experience in demonstrating systems at Hanford.

The team's investigation was intended to be exhaustive, but representative of the types of technologies available. Data on 15 various tools and systems was compiled.

A matrix is provided below with information on two products. The purpose of this matrix is to illustrate the type of analysis that can be conducted to compare and contrast technologies. The technology criteria described in section 6.3 are a large basis for the analysis. The two technologies described are both gamma scanning systems - RadScan from BNFL and 600(700) and GammaCam from AIl. They are both used for finding gamma emitting radionuclides in a building (including piping). Both products are remotely controlled and contain the ability to visually depict contaminated spots in an area. RadScan 600(700) uses a digital video camera and laser which determine the distance while GammaCam uses a photo camera. Both systems have the ability to save the data on a remote computer. 
Table 6.4 Suppliers of Various Instrumentation for Neutron/Beta/Gamma Measurements

(From Dave Robertson's Group at PNNL)

\section{Intrinsic Germanium Detectors}

Canberra Industries

EG\&G Ortec

Oxford Instruments

Eurisiys Mesures

Princeton Gamma Tech (PGT)

Aptec

AEA Detectors

Canberra Industries

EG\&G Ortec

\section{Nal Detectors/Scintillation detectors}

Bicron

Scionix

Aptec

National Nuclear Corporation

Neutron Counters

N.Wood Counter laboratory

Reuter-Stokes

Ordela

Oxford Instruments

\section{Liquid Scintillation Counters}

Packard Instruments

Quantulus

\section{Electronic-Nim Bin type}

Canberra Industries

EG\&G Ortec

Oxford Instruments

Eurisiys Mesures

Princeton Gamma Tech (PGT)

Aptec

\section{Alpha/Beta}

Packard Instruments Company

Eurisiys Mesures 
The matrix in Table 6.5 describes the systems in a fair amount of detail. The advantages and disadvantages are a critical component to consider in trying to decide which system is more appropriate for the ChNPP. Here are some of the critical factors found from secondary sources:

- RadScan 600(700) has the capability of low resolution spectrometry which allows the user to detect and distinguish Cs-137 and Co-60 while GammaCam can not.

- RadScan operates in a larger spectrum of radiation

- AIl does not have a branch in Europe while BNFL (RadScan) does (Budapest, Hungary) which affects delivery support ease

- The price for the two units is somewhat comparable

Here are some of the critical findings from consulting with primary sources (Grant Cefallo):

- GammaCam has better sensitivity and precision than RadScan

- RadScan is larger and heavier than GammaCam, making RadScan more difficult to use if portability is critical.

This information is helpful but not conclusive in choosing between the two systems. Further analysis would be required which could be expedited by conducting the following steps:

1. Request detailed technical descriptions from the companies

2. Study the experience of the sites that have used the systems, including interviewing relevant personnel

Find out the possibilities of the two companies demonstrating their systems at ChNPP with ChNPP staff involved to determine which system is more appropriate for their needs.

This description of these two systems is used to illustrate the type of analysis that is needed to thoroughly evaluate technologies. Such analysis could benefit the ChNPP. 
Table 6.5 Example of Radiological Survey Technologies for the ChNPP Prior to Decommissioning

Scanning technologies Gamma Scanning

\begin{tabular}{|c|c|c|c|c|c|c|c|c|}
\hline \multirow{2}{*}{$\begin{array}{c}\text { Name } \\
\text { (company, product, } \\
\text { contacts) }\end{array}$} & \multirow[t]{2}{*}{ Description } & \multicolumn{3}{|c|}{ Performance } & \multirow{2}{*}{$\begin{array}{c}\text { Limitation/ } \\
\text { Utility } \\
\text { Requirements }\end{array}$} & \multirow{2}{*}{$\begin{array}{c}\text { Experience of } \\
\text { Applying }\end{array}$} & \multirow{2}{*}{$\begin{array}{c}\text { Cost/Delivery/ } \\
\text { Support }\end{array}$} & \multirow{2}{*}{$\begin{array}{c}\text { Advantages/ } \\
\text { Disadvantages }\end{array}$} \\
\hline & & Sensitivity & Accuracy & Etc. & & & & \\
\hline $\begin{array}{l}\text { BNFL } \\
\text { Instruments } \\
\text { Ltd. } \\
\text { Product: } \\
\text { RadScan } 600 \\
\text { (700) } \\
\text { Tel.:+44( 0) } \\
1946785017\end{array}$ & $\begin{array}{l}\text { A gamma sensitive } \\
\text { shielded/collimation } \\
\text { detector (CsI) with } \\
\text { gamma } \\
\text { spectroscopy, laser } \\
\text { range finder, video } \\
\text { camera. Controlled } \\
\text { by PC based remote } \\
\text { control station. } \\
\text { Provides real time } \\
\text { remote } \\
\text { measurements of the } \\
\text { surface } \\
\text { contamination and } \\
\text { exposure levels of } \\
\text { gamma ray-emitting } \\
\text { isotopes (Cs-137, } \\
\text { Co-60) }\end{array}$ & $\begin{array}{l}<1 \mathrm{mCi} \text { for } \\
\mathrm{Cs} 137 \text { in } \\
\text { field of view } \\
\text { at } 1 \mathrm{~m} \text {; } \\
<1 \mathrm{~g} \text { for } \mathrm{U} 235 \\
\text { in field of } \\
\text { view at } 1 \mathrm{~m}\end{array}$ & $\begin{array}{l}\text { Low } \\
\text { resolution } \\
\text { gamma ray } \\
\text { spectrometry } \\
\text { Accuracy not } \\
\text { as good as } \\
\text { GammaCam } \\
\text { (according to } \\
\text { G. Ceffalo- } \\
\text { BHI) }\end{array}$ & $\begin{array}{l}\text { Detects gamma } \\
\text { rays between } \\
100 \mathrm{keV} \text { and } 10 \\
\mathrm{MeV}\end{array}$ & $\begin{array}{l}\text { Detection range } \\
1-50 \mathrm{~m} \\
\text { Weights } 400 \mathrm{lbs} \text {; } \\
\text { makes portability } \\
\text { difficult }\end{array}$ & $\begin{array}{l}\text { - Successfully used } \\
\text { at UKAEA's } \\
\text { Winfirth facility in } \\
\text { Dorset, England, } \\
\text { - Successfully used } \\
\text { by NIS } \\
\text { Ingenieurgesellsch } \\
\text { aft mbH based in } \\
\text { Hanau, Germany } \\
\text { - Hanford site: B } \\
\text { Plant } \\
\text { - Future deployment: } \\
\text { D\&D Projects at } \\
\text { Hanford 100-K }\end{array}$ & $\begin{array}{l}\$ 185,000+10 \% \\
\text { tax, } \\
\text { delivery in } 10 \\
\text { days } \\
\text { Eastern } \\
\text { European office }\end{array}$ & $\begin{array}{l}\text { + Device can locate } \\
\text { small quantities of } \\
\text { contamination next to } \\
\text { much larger quantities. } \\
+ \text { Determines isotopic } \\
\text { distribution of the } \\
\text { source } \\
+ \text { Color video } \\
\text { recording of each } \\
\text { measurement can be } \\
\text { overlaid onto } \\
\text { radiometric field of } \\
\text { view } \\
\text { - Heavy } \\
\text { - Not quite as accurate } \\
\text { as GammaCam }\end{array}$ \\
\hline $\begin{array}{l}\text { AIL System, Inc. } \\
\text { Product: } \\
\text { GammaCam }^{\text {TM }} \\
\text { Al Henneborn } \\
\text { AIL System, Inc. } \\
455 \text { Commack Road } \\
\text { Deer Park, NY } \\
\text { 11729-4591 } \\
\text { (516) 595-6669 } \\
\text { (800) 944-1180 } \\
\text { http://www.ail.com }\end{array}$ & $\begin{array}{l}\text { The GammaCam } \\
\text { system provides a } \\
\text { two-dimensional } \\
\text { pseudo-color image } \\
\text { of gamma-ray } \\
\text { radiation. System } \\
\text { consists of a sensor } \\
\text { head (gamma-ray } \\
\text { and visual imaging } \\
\text { systems) and a } \\
\text { portable computer. }\end{array}$ & $\begin{array}{l}\text { Gamma-ray } \\
\text { energy } \\
\text { sensitivity } \\
0.1 \text { to } 2.0 \\
\mathrm{MeV}\end{array}$ & $\begin{array}{l}\text { Good } \\
\text { accuracy }\end{array}$ & \begin{tabular}{|l|} 
Spectral range: \\
$<80 \mathrm{keV}$ to \\
$>1.3 \mathrm{MeV}$ \\
Dynamic range: \\
Instrument:>10E7 \\
Single \\
image:>10:1 \\
\\
Data acquisition \\
10 milliseconds to \\
many hours \\
Can be used in \\
fields as high as \\
50 rad/hour
\end{tabular} & $\begin{array}{l}\text { Detection range } \\
1-200 \text { feet } \\
\text { Weight around } 50 \\
\text { lbs., very portable } \\
\text { Requires } 120 \\
\text { VAC power which } \\
\text { may be a problem } \\
\text { in remote areas } \\
\text { Training in the } \\
\text { setup and use only } \\
\text { takes a few hours } \\
\text { Setup of device } \\
\text { takes } 30 \text { minutes }\end{array}$ & $\begin{array}{l}\text { - Successfully } \\
\text { demonstrated at } \\
\text { Chicago Pile 5 } \\
\text { (CP-5) Research } \\
\text { Reactor (1996); } \\
\text { - Successfully used at } \\
\text { the Hanford Site (B- } \\
\text { plant decom- } \\
\text { missioning), } \\
\text { - Being used at } \\
\text { numerous } \\
\text { commercial nuclear } \\
\text { facilities during } \\
\text { refueling operations. } \\
\text { - Used at the several } \\
\text { locations at INEEL } \\
\text { and LANL } \\
\text { - Naval Nuclear } \\
\text { Training Facility at } \\
\text { Paldiski, Estonia. }\end{array}$ & $\begin{array}{l}\text { Purchase: } \\
\$ 163,000- \\
\$ 200,000 \\
\text { Vendor provide } \\
\text { instruction: } \\
\$ 5,817 \\
\text { Equipment } \\
\text { Lease: } \\
1 \text { Month } \\
30,000 \$ \\
2 \text { Month } \\
25,000 \$ / \text { month } \\
3 \text { Month } \\
20,000 \$ / \text { month } \\
\\
\text { No Eastern } \\
\text { European office }\end{array}$ & $\begin{array}{l}\text { - Does not determine } \\
\text { isotopic distribution - } \\
\text { cannot be used as a } \\
\text { spectrometer. } \\
\text { + Provides an } \\
\text { electronic visual record } \\
\text { + System can be used } \\
\text { in areas containing } \\
\text { extensive piping } \\
\text { - The coded aperture } \\
\text { has some limitations } \\
\text { - Need to watch for } \\
\text { image artifacts under } \\
\text { certain conditions } \\
+ \text { Provides useful } \\
\text { information on number, } \\
\text { location, and intensity } \\
\text { of rad sources } \\
\text { - No office in Eastern } \\
\text { Europe }\end{array}$ \\
\hline
\end{tabular}




\subsection{LESSONS LEARNED}

Nuclear site decommissioning is a complex and multifaceted task. At a minimum, it demands a significant amount of effort from all relevant parties including the site operator (including engineers, designers (architects), environmental scientists and engineers) and regulators. The team learned that an explicit process is needed that defines the decommissioning approach for it to be efficient. A regulatory basis is needed to not only govern the process but to define the set of measurements and samples that need to be taken. This is particularly true for the radiological characterization stage prior to decommissioning, to ensure that an enormous number of samples is not taken when a smaller number can meet the data quality objectives. Sampling costs (and time) alone have been great at sites that failed to institute a prescriptive approach. Some nations have substantial experience in nuclear site decommissioning and have still managed to make these mistakes. It is the Team's opinion that nations, such as Ukraine, where decommissioning activities are new, should learn from these mistakes and follow those examples where nations have used a strong planning approach.

Radiological characterization prior to decommissioning is an absolutely critical step to determining the decommissioning process. As mentioned, planning an efficient characterization is important. The quality of the characterization survey is dependent on the methods, technology systems, and individual tools used. TSA is an important tool to help design the method, and identify and select the most appropriate technology systems and tools. This is particularly true in an ever-growing information world where the choices are becoming every greater. Keeping track of trends and emerging technologies is greatly helped by using a TSA system.

The success of applying a TSA process depends on having access to secondary sources. It is impossible to overestimate the assistance a search tool like Dialog can provide. One such tool can supply information from hundreds of databases simultaneously. TSA cannot be conducted without access to such search engines.

Secondary source information is helpful and can serve as a good basis to preparing a TSA team member for accessing primary sources (experts). Such primary sources can be critical to providing first-hand experience and insights into a problem. Their value judgements can help enrich secondary source information.

TSA will serve as an effective tool only if the process of gathering and analyzing data is iterative and built upon. Furthermore, TSA is best applied if used as an on-going process not a one-time effort to address one problem.

Finally, the TSA Team found the Americans it dealt with to be extremely open and helpful in sharing information and guiding the Team. 


\subsection{RECOMMENDATIONS}

The TSA Team compiled the following list of actions that it recommends occur to apply the findings from the project and to further develop TSA as a capability. The Team presented these recommendations to a Hanford audience of key experts on March 30, 1999:

- Plan to present findings and recommendations to the Team members' organizations and to the organizations directly participating in the process of ChNPP decommissioning;

- Describe to the Ukrainian regulators and ChNPP decommissioning staff the US and other international experience in radiological surveying prior to decommissioning, and support them in implementing such an approach;

- Plan to look for other opportunities to conduct the TSA process;

- Try to ensure that TSA is an on-going process within the Team members' organizations;

- Aquire access to Dialog to support TSA function

The Hanford audience recommended that TSA be institutionalized as a process for doing business at SLIRT and the Chornobyl Center. One member mentioned that it would be a beneficial tool to help justify budgets in buying equipment needed for ChNPP. Another member mentioned using it to support technology decisions for the RadioEcology Laboratory. Members were also interested in providing support to the Team in arranging opportunities to present their findings to Ukrainian decision makers. 


\subsection{BIBLIOGRAPHY}

Abel, K.H., Robertson, D.E. et al. 1986. Residual Radionuclide Contamination Within and Around Commercial Nuclear Power Plants, NUREG/CR-4289, PNL-5429.

ASTM Committee E-10 on Nuclear Technology and Applications. 1998. Standard Guide for Selection and Use of Portable Radiological Survey Instruments for Performing In Situ Radiological Assessment in Support of Decommissioning. E-1893-97.

Berger, J.D. 1992. Manual for Conducting Radiological Surveys in Support of License Termination, NUREG/CR-5849, ORAU-92/C57, Oak Ridge Associated Universities.

Buckley, W.M., Carlson, J.B. and Neufeld, K.W. 1995. High-Resolution Gamma-Ray Measurement System Using a Compact Electromechanically Cooled Detector System and Intelegent Software, Transactions of the American Nuclear Society.

Cremer C.D., Cramer, E. and Lowry, W. 1994. Laboratory Evaluation of the Pipe Explorer Gamma Measurment and Deployment Capability, Science \& Engineering Associates, Inc.

Dulloo, A.R., Congedo, T.V., Ruddy, F.H., Seidel, J.G., Williams, R.P., and Weigle, D.H. 1995. Detection of Contaminants in Concrete Surfaces Using Prompt Gamma Neutron Activation Analysis, Transactions of the American Nuclear Society, Vol. 73, p. 61.

Ezure, H. 1998. Survey of Estimation Methods for Radioactive Inventory in Nuclear Reactors to be Decommissioned, Journal of Nuclear Science and Technology, Vol. 35, no. 5, Atomic Energy Soc. Japan, p. 379-94.

Gammage, R.B and Wheeler, R.V. 1993. Testing CR-39 for surface alpha contamination monitoring, Health Physics, Vol. 65, no. 2, Oak Ridge Nat. Lab., TN, USA, pp. 209-13.

Gammage, R.B., DePriest, J.C., Wheeler, R.V., Dempsey, J.C. and Kotrappa, P. 1992. Monitoring of Surface Alpha Contamination with Expensive Passive Monitors, Oak Ridge National Laboratory, TN.

Holoway, C.F. et al. 1981. Monitoring for Compliance With Decommissioning Termination Survey Criteria, NUREG/CR-2082, ORNL/HASRD-95, Oak Ridge National Laboratory.

Hughes, K.A. and Lightfoot, J.A. 1996. RadScan600 - A Portable Instrument for the Remote Imaging of Gamma Contamination: Its Design and use in Aiding Decommissioning Strategy, 1996 IEEE Nuclear Science Symposium Conference Record, Vol. 2, IEEE, New York, NY, USA, pp. 930-933. 
Hughes, K.A. and Lightfoot, J.A. 1997. Locating those hard-to-find "hot spots", Nuclear Engineering International, Vol. 42, no. 513, p. 16-17.

International Atomic Energy Agency (IAEA). 1998. Radiological Characterization Shut Down Reactors for Decommissioning Purposes. Technical Reports Series No. 389.

Islam, K.T.S., Johnson, L., Brey, R.R., Gesell, T.F. and McIsaac, C. 1996. Evaluation of a Low Background Proportional Counter for Detection of High Energy Beta Particles with Application to [sup 90] Sr Surface, Health Physics, Vol. 70, supp. 6, p. 17-18.

Kasper, K. 1998. SRA's surface contamination monitor, Health Physics, Vol. 74, no. 5, Wlliams \& Wilkins, p. 543-4.

Lepel E.A., Robertson, D.E. et al. 1995. Radiological Characterization of Spent Control Rod Assemblies, NUREG/CR-6390, PNL-10806.

Lepel, E.A. et al. 1995. Radiological Characterization of Spent Control Rod Assemblies, Journal of Radioanalytical and Nuclear Chemistry, Vol. 194(1), Elsevier Science Publishers Ltd, pp. 81-94.

Lepel, E.A., Brodzinski, R.L., Reeves, J.H. and Kohli, R. 1998. A flexible, selfcontained germanium spectrometer for the in-situ measurment of gamma-ray emitting radionuclides in and around piping, Journal of Radioanalytical and Nuclear Chemistry, Vol. 233:1-2, p. 173-176.

MacArthur, D.W. 1995. Alpha Detection for Decontamination and Decommissioning:

MacArthur, D.W., Allander, K.S., Koster, J., Rawood-Sullivan, M., Rojas, S. and Sprouse, L. 1994. Alpha Detection for Characterisation of D\&D Sites, Transactions of the American Nuclear Society, Vol.71, p. 620.

Manion, W.J. 1990. Key issues in the planning for commercial reactor decommissioning, Excellent and Economic Nuclear Plant Performance American Society of Mechanical Engineers, Nuclear Engineering Division, Vol. 4, ASME, New York, p. 89-90.

Matusevish, E.S. and Cherkashin, V.A.. no date. Development of Sampling Methodic of Radioactive Materials and Measurements in Performing Radioactive Inspection of APS, Transactions of the American Nuclear Society, Vol. 67, supp. 1.

Miller, K.M., Reginatto, M., Shebell, P., Klemic, G.A. and Gogolak, C.V. 1997. Spectrometric Techniques for the Measurement of Radioactive Contamination in Buildings, Proceedings of the Air \& Waste Management Association's 90th Annual Meeting \& Exhibition. 
Mottershead, G. and Orr, C.H. 1996. A gamma scanner for pre-decommissioning monitoring and waste segregation, Nuclear Engineer, Vol. 37, no 1, S\&K Publishing for Institution of Nuclear Engineer, p. 3-7.

Oak Ridge National Laboratory. 1996. Pipe Explorer [sup (trademark)] System. Innovative Technology Summary Report.

Rawool-Sullivan, M.W., Allander, K.S., Bounds, J.A., Koster, J.E., MacArthur, D.W., Sprouse, L., Stout, D., Vaccarella, J.A. and Vu, T.Q. 1994. Study of Alpha Characterrization of a D\&D Site Using Long-Range Alpha Detectors, Los Alamos National Laboratory.

Rawool-Sullivan, M.W., Bolton, R.D., Conaway, J.G. and MacArthur, D.W. 1996. Alpha Contamination Assessment for D\&D Activities: Monitoring Inside Glove Boxes and Vessels, Los Alamos National Laboratory.

Results and Possibilities, Los Alamos National Laboratory.

Robertson, D.E. et al. 1993. Radionuclide Characterization of Reactor Decommissioning Waste and Neutron-Activated Metals NUREG/CR-5894, PNL-8106.

Ronaldson, J.P. and Orr, C.H. 1996. Radiometric Tools for Decommissioning, Nuclear Europe Worldscan, Vol. 16, no. 3-4, Europe Nuclear Society, p. 51-52.

Russo, P.A. et al. 1995. A New, Room-Temperature Gamma-Ray Detector for Improved Assay of Plutonium, Los Alamos National Laboratory.

Russo, P.A., Smith, H.A., Sprinkle, J.K., Bjork, C.W., Sheppard, G.A., Ensslin, N. and Smith, S.E. 1995. Evaluation of an Integrated Holdup Measurement System Using the GGH Formalism with the M3CA, Transactions of the American Nuclear Society.

Schreiner, S.I. 1994. Internal Pipe Inspection Devices for Use in Radiation Survey Applications, Transactions of the American Nuclear Society, Vol.71, p.514-15.

U.S. Atomic Energy Commission. 1974. Regulatory Guide 1.86 Termination of Operating Licenses for Nuclear Reactors.

U.S. Nuclear Regulatory Commission. 1988. Decommissioning Criteria for Nuclear Facilities 10CFR 30.36, 40.42, 50.82, 70.38, 72.54 .

U.S. Nuclear Regulatory Commission. 1997. Multi-Agency Radiation Survey and Site Investigation Manual (MARSSIM), NUREG-1575.

Vu, T.Q., Rawool-Sullivan, M.W., Koster, J., Stout, D., and Beasinger, A. 1995. Alpha Characterization of Concrete Surfaces at Decontamination \& Decommisioning (D\&D) Sites, Los Alamos National Laboratory. 
Wade, C.D. 1997. Technical Basis for Performance of Radiological Surveys in Support of Nuclear Facility Decommissioning/Deactivation Utilizing the Laser-Assisted Ranging and Data System (LARADS), Betchel Hanford, Inc. Richland, WA. 


\section{APPENDIX A. MATRIX OF SECONDARY SOURCES REVIEWED}

\begin{tabular}{|c|c|c|}
\hline Title & Authors & Abstract \\
\hline $\begin{array}{l}\text { Technique } \\
\text { Radiological Characterization } \\
\text { of Spent Control Rod } \\
\text { Assemblies }\end{array}$ & Lepel, E.A. et al. & $\begin{array}{l}\text { Objective: The direct assay techniques are powerful tools that can be used to measure the radionuclides, especially high-activity } \\
\text { components such as spent control rods because of their very high dose rates. Two direct-assay methods (DAM) have been } \\
\text { employed to determine the Curie contents of the neutron-activated metal components of the spent control rod assemblies (SCRA). } \\
\text { Description: One of these, which was described in detail in, Robertson, et. al (1993), consist of: 1) direct gamma ray spectrometry } \\
\text { to identify those radionuclides contributing to the gamma dose rate, 2) thermoluminescent dosimetry (TLD) to measure the gamma } \\
\text { dose rate along the length of the control rod, } 3 \text { ) dose-to-Curie conversion using appropriate shielding/geometry codes, and 4) } \\
\text { correlations (scaling) to the } 60 \text { Co to estimate the concentrations of other 10CFR61 radionuclides in the assemblies. } \\
\text { Technology provider: PNNL. } \\
\text { Time required to take one measurement: Without calculations - } 10-30 \text { min. } \\
\text { Complexity of the instrument: A portable intrinsic germanium gamma-ray detector with software, TLD detector. } \\
\text { NDA ability of a device: } \\
\text { Performance: As usual detectors } \\
\text { Cost: } \\
\text { Experience in applying the technology: In } 1993 \text { were radiologically characterized: a BWR cruciform control rod, a PWR rod- } \\
\text { cluster control assembly, a burnable poison-rod assembly. } \\
\text { Conclusion: DAM, due to agreement with laboratory data lends confidence that the direct assay methodologies can provide very } \\
\text { accurate determination of the radionuclides inventories of SCRA and other types of highly neutron-activated metal wastes. }\end{array}$ \\
\hline $\begin{array}{l}\text { Instrument } \\
\text { RadScan600 - A Portable } \\
\text { Instrument for the Remote } \\
\text { Imaging of Gamma } \\
\text { Contamination: Its Design } \\
\text { and use in Aiding } \\
\text { Decommissioning Strategy }\end{array}$ & $\begin{array}{l}\text { K.A. Hughes and } \\
\text { J.A. Lightfoot }\end{array}$ & $\begin{array}{l}\text { Objective: RadScan } 600 \text { has been developed to allow the remole surveying of gamma radiation with identifying "hot spots" in a } \\
\text { wide variety of environments. } \\
\text { Technology provider: BHFL Instruments, Ltd. } \\
\text { Time required to take one measurement: Scanning speed (RadScan700) } 2-4 \text { degree/sec pan, } 1-2 \text { deg./sec tilt. } \\
\text { Complexity of the instrument: The device is based on a CsI (TI) crystal located in a tungsten collimator. A color CCD camera } \\
\text { produces a visual image of the area undergoing survey. RadScan is operated from a remote, safe location using a PC-based } \\
\text { Workstation. } \\
\text { NDA ability of device: }+ \\
\text { Performance: <1mCi to } 0.2 C \text { for Cs-137 in field of view at } 1 \mathrm{~m} \text {, detecting gamma rays with energies between } 100 \mathrm{keV} \text { and } 10 \mathrm{MeV} \\
\text { Cost: } \\
\text { Experience in applying the technology: UKAEA's Winfrith facility in Dorset, England to survey remotely contamination contained } \\
\text { in Post-Irradiation Examination cells. It is employed by NIS Ingenieurgesellschaft mbH based in Hanau, Germany to provide } \\
\text { estimates of dose rates. It has been used on a number of nuclear plants currently being decommissioned at Sellafield. } \\
\text { Conclusion: The information provided by this instrument can be used for a number of purposes, these include: Assessing a } \\
\text { gamma source's contribution to a dose rate; Quantifying the success of a clean-up operation; Aiding in the design of shielding; } \\
\text { Locating radiation sources in high dose rate environs. }\end{array}$ \\
\hline $\begin{array}{l}\text { Instrument } \\
\text { Internal Pipe Inspection } \\
\text { Devices for Use in Radiation } \\
\text { Survey Applications }\end{array}$ & Schreiner, S.I. & $\begin{array}{l}\text { Objective: A set of pipe crawlers has been developed to provide detailed radiological surveys using G-M delectors at precise } \\
\text { location in 4- to } 12 \text {-in. -diam internal pipe surfaces. } \\
\text { Technology provider: LILCo, Shoreham } \\
\text { Time required to take one measurement: } \\
\text { Complexity of the instrument: G-M detector, an enhanced electronics package was also developed that consist of control } \\
\text { module, videocassette recorder, monitor, videocamera with reel, cable foot encoder, and a video data logger. This allows for } \\
\text { videos and photographs of radiation surveys with all location and pipe run information to be superimposed on the screen. } \\
\text { NDA ability of device: }+ \\
\text { Cost: The ability to inspect thousands of feet of embedded and exposed piping resulted in savings of over } \$ 13 \text { million at SNPS. } \\
\text { Experience in applying the technology: } 6800 \mathrm{ft} \text { of embedded piping has been successfully surveyed at the Shoreham NPS } \\
\text { which is being decommissioned. In addition, } 8300 \mathrm{ft} \text { of piping that was not embedded has been successfully surveyed with pipe } \\
\text { crawlers. } \\
\text { Conclusion: The key to the benefit of these pipe crawlers is their ability to measure down to "free-release" levels. }\end{array}$ \\
\hline
\end{tabular}




\begin{tabular}{|c|c|c|}
\hline Title & Authors & Abstract \\
\hline $\begin{array}{l}\text { Technique, } \\
\text { Instrument } \\
\text { Testing CR-39 for Surface } \\
\text { Alpha Contamination } \\
\text { Monitoring }\end{array}$ & $\begin{array}{l}\text { Gammage, R.B } \\
\text { and Wheeler, R.V. }\end{array}$ & $\begin{array}{l}\text { Objective: Alpha- sensitive, track-etch plastic detectors (ATDs) offer attractive potential for resolution of some problems } \\
\text { concerning with alpha contamination monitoring. } \\
\text { Technology provider: Oak Ridge National Laboratory, Lantrak plastic ATDs provided by Landauer, Inc. } \\
\text { Time required to take one measurement: } 20-100 \text { min. without etching. } \\
\text { Complexity of an instrument: plastic detector (Lantrak is a CR-39-type materials), visualization of individual damage tracks left by } \\
\text { impinging alpha particles was achieved by postexposure etching in a caustic solution. } \\
\text { NDA ability of device: }+ \\
\text { Performance: At } 3.67 \mathrm{~Bq} 100 \mathrm{~cm}(-2)(220 \mathrm{dpm} 100 \mathrm{~cm}(-2)) \text {, a } 10: 1 \text { signal-to-noise ratio is obtained after about a } 100-\text { min exposure; } \\
\text { the detector background level in control detectors handled normally but with no intentional exposure, is } 13+/-10 \text { tracks } \mathrm{cm}(-2) \text {. } \\
\text { Cost: Low cost per measurement (few dollars) } \\
\text { Experience in applying the technology: } \\
\text { Conclusion: The ATDs seem especially attractive for measurements in difficult to access location during repeated cleanings. } \\
\text { Significant advantages og ATDs are: High detection efficiency for alpha radiation and complete insensitivity to gamma and beta } \\
\text { radiations; A technician can place individual detectors at hundreds of sites in a single day and retrieve the detectors on either the } \\
\text { same day or on the following day. }\end{array}$ \\
\hline $\begin{array}{l}\text { Instrument } \\
\text { SRA's Surface } \\
\text { Contamination Monitor }\end{array}$ & Kasper, K. & $\begin{array}{l}\text { Objective: Radiation survey should be performed very quickly for large areas. } \\
\text { Technology provider: Shonka Research Associates, Inc. } \\
\text { Time required to take one measurement: Area release surveys are } 3 \text { (alpha) to } 7 \text { (beta-gamma) times faster than manual } \\
\text { surveys; data analysis and reporting is } 5 \text { to } 10 \text { times faster than manual surveys. } \\
\text { Complexity of the instrument: Surface Contamination Monitor and Survey Information Management System (SCM/SIMS) is a } \\
\text { versatile platform for deploying a variety of radiological detection instruments. Detectors are attached to a motorized, gear-driven } \\
\text { cart equipped with a comprehensive data collection and analysis system. For floor and wall surfaces, the SCM/SIMS has been } \\
\text { successfully using a 4-m-long, position-sensitive gas-proportional counter. } \\
\text { NDA ability of device: + } \\
\text { Performance: } 400 \text { radiation measurements with positional data in an area of a single square meter. Automatically generated } \\
\text { survey reports provide two- and three-dimensional views of the data sets with corresponding numerical averages, minimum and } \\
\text { maximum values, and standard deviations. } \\
\text { Cost: Overall costs savings are about } 30 \% \text { (compare with manual survey) } \\
\text { Experience in applying the technology: SCMS/SIMS was used for a characterization survey of the 108F Facility at Hanford and } \\
\text { detected the presence of plutonium in areas that were previously thought to be "clean". It also used on a survey of over } 127,000 \\
\text { ft2 at DOE-Idaho's Air Support Building in a 2-week effort under harsh environmental conditions. } \\
\text { Conclusion: Very useful tool for large areas radiation survey. For further information on the SCM/SIMS we should contact Joseph } \\
\text { Shonka of SRA at (707) 509-7606. Innovative Technology Summary Report, developed by DOE's Office of Science and } \\
\text { Technology is available through OST's Internet site at em-52.em.doe.gov/ffd/ost/pubs.htm. }\end{array}$ \\
\hline $\begin{array}{l}\text { Technique } \\
\text { Software } \\
\text { Evaluation of an Integrated } \\
\text { Holdup Measurement } \\
\text { System Using the GGH } \\
\text { Formalism with the M3CA }\end{array}$ & $\begin{array}{l}\text { Russo, P.A., } \\
\text { Smith, H.A.', } \\
\text { Sprinkle, J.K., } \\
\text { Bjork, C.W., } \\
\text { Sheppard, G.A., } \\
\text { Ensslin, N. and } \\
\text { Smith, S.E. }\end{array}$ & $\begin{array}{l}\text { Objective: Nuclear facilities worldwide need portable automated tools based on gamma-ray spectrometry to perform plantwide } \\
\text { assays of special nuclear material (SNM) deposited as holdup in equipment. } \\
\text { Technology provider: Los Alamos National Laboratory } \\
\text { Time required to take one measurement: } \\
\text { Complexity of the instrument: Software, called HMSII (Holdup Measurement System II), is run by the control unit and masks the } \\
\text { sophistication of the hardware and data analysis with a simple user interface. The heart of the integrated holdup measurement } \\
\text { system is the generalized-geometry holdup (GGH) calibration and analysis formalism. The GGH formalism is based on the } \\
\text { simplifying assumption that each of hundreds of unique holdup deposit geometries can be interpreted as one of three simple } \\
\text { geometric models (point, line. and area) to reduce the calibration and analysis effort to manageable proportions. } \\
\text { NDA ability of device: + } \\
\text { Performance: } \\
\text { Cost: } \\
\text { Experience in applying the technology: The GGH formalism has been tested and verified quantitatively at Rocky Flats Plant } \\
\text { 371 Precipitator Canyons (1987), High- Throughput Bulk-Processing Equipment (1990). } \\
\text { Conclusion: Useful instrument, but the future development of this sotware need to be explore. }\end{array}$ \\
\hline
\end{tabular}




\begin{tabular}{|c|c|c|}
\hline Title & Authors & Abstract \\
\hline $\begin{array}{l}\text { Instrument } \\
\text { Software } \\
\text { High-Resolution Gamma-Ray } \\
\text { Measurement System Using } \\
\text { a Compact } \\
\text { Electromechanically Cooled } \\
\text { Delector System and } \\
\text { Intelegent Software. }\end{array}$ & $\begin{array}{l}\text { Buckley, W.M., } \\
\text { Carlson, J.B. and } \\
\text { Neufeld, K.W. }\end{array}$ & $\begin{array}{l}\text { Objective: Obtaining high-resolution gamma-ray measurements using hyperpure germanium (HPGe) detectors in the field has } \\
\text { been of limited practicality due to the need to use and maintain a supply of liquid nitrogen (LN). This same constraint limits high } \\
\text { resolution gamma measurements in unattended safeguards or treaty verification applications. System based on a compact } \\
\text { electromechanically cooled HPGe detector and appropriate software are developing. } \\
\text { Technology provider: Lawrence Livermore National Laboratory. } \\
\text { Time required to take one measurement: } \\
\text { Complexity of the instrument: } \\
\text { NDA ability of device: } \\
\text { Performance: } \\
\text { Cost: } \\
\text { Experience in applying the technology: } \\
\text { Conclusion: Interesting approach, but the future development of this technique and software need to be explore. }\end{array}$ \\
\hline $\begin{array}{l}\text { Instrument } \\
\text { A New, Room-Temperature } \\
\text { Gamma-Ray Detector for } \\
\text { Improved Assay of Plutonium }\end{array}$ & $\begin{array}{l}\text { P.A. Russo and } \\
\text { others }\end{array}$ & $\begin{array}{l}\text { Objective: The most recent developments in room-temperature solid-state gamma-ray detectors indicate that the capabilities of } \\
\text { compound semiconductor detectors such as CdZnTe with novel electrode designs include significant improvements over the } \\
\text { energy resolution provided by Nal detectors as well as very compact dimensions. These new detectors are fully compatible with } \\
\text { newest compact gamma-ray spectroscopy systems designed for portable and unattended applications. } \\
\text { Technology provider: LANL, Lawrence Berkeley Laboratory, eV Products (A division of II-VI Corporation). } \\
\text { Time required to take one measurement: As usual. } \\
\text { Complexity of the instrument: As usual. } \\
\text { NDA ability of device: }+ \\
\text { Performance: FWTM/FWHM at } 662 \mathrm{keV}=2: 1(10-1000 \mathrm{keV}) . \\
\text { Cost: } \\
\text { Experience in applying the technology: Experiment stage. } \\
\text { Conclusion: Worth bearing in mind. }\end{array}$ \\
\hline $\begin{array}{l}\text { Instrument } \\
\text { Technical Basis for } \\
\text { Performance of Radiological } \\
\text { Surveys in Support of } \\
\text { Nuclear Facility } \\
\text { Decommissioning/ } \\
\text { Deactivation Utilizing the } \\
\text { Laser-Assisted Ranging and } \\
\text { Data System (LARADS) }\end{array}$ & C.D. Wade & $\begin{array}{l}\text { Objective: Describe the implementation of the Laser-Assisted Ranging and Data System (LARADS) as it applies to performing } \\
\text { radiological surveys on facility exterior and interior surfaces. The LARDAS enables the system operator to document scanning } \\
\text { measurements, stationary radiological measurements, and sample locations of surfaces, with the radiological readings and exact } \\
\text { coordinates (<2cm precision) automatically logged in real-time. After the survey is completed, the information is overlaid on a } \\
\text { digital picture of the survey area or may be generated as a computer-aided drafted drawing. The final product is a track map or } \\
\text { contour of the survey area that clearly shows the area covered by the detector and locations of elevated readings. } \\
\text { Technology provider: BHI. } \\
\text { Time required to take one measurement: Scanning. } \\
\text { Complexity of the instrument: The Eberline E-600 ratemeter contains analog circuitry that may be configured under } \\
\text { microprocessor control to support a variety of detector types. The instrumentation is commercially available and unmodified, and } \\
\text { data are uncorrupted when configured with the positioning system component. The Eberline E-600 has been field tested and } \\
\text { meets the criteria specified by the American National Standards Institute (ANSI) in ANSI N42.17A-1989 } \\
\text { NDA ability of device: }+ \\
\text { Performance: When E-600 combined with the model SHP-380 alpha/beta detector, it can simultaneously monitor residual alpha } \\
\text { and beta activity at levels below the regulatory table values applicable to total contamination per } 100 \text { cm2. The E-600 also may be } \\
\text { configured with various gamma detectors to establish dose-rate profiles within the facility. The total station component tracks the } \\
\text { position of the detector and downloads the } x, y, \text { and } z \text { coordinates to a computer every second. The detector is fitted with a target } \\
\text { prism and the total station locks onto the crystal with a laser beam and tracks the survey as it progresses. The total station } \\
\text { calculates the positional data and relays the data to, the computer for storage. A customized software program ties the location to } \\
\text { specific radiological data through the process of time stamping. } \\
\text { Cost: } \\
\text { Experience in applying the technology: } \\
\text { Conclusion: Worth keeping in mind. }\end{array}$ \\
\hline
\end{tabular}




\begin{tabular}{|c|c|c|}
\hline Title & Authors & Abstract \\
\hline $\begin{array}{l}\text { Research for regulation } \\
\text { Radiological Characterization } \\
\text { of Spent Control Rod } \\
\text { Assemblies } \\
\text { NUREG/CR-6390 } \\
\text { PNL-10806 }\end{array}$ & $\begin{array}{l}\text { E.A. Lepel, D.E. } \\
\text { Robertson, and } \\
\text { other }\end{array}$ & $\begin{array}{l}\text { This work has addressed the following objectives: } 1 \text { ) radiological characterization and classification of intensely radioactive } \\
\text { materials removed from the reactor pressure vessel, including spent control rod assemblies (SCRA) from commercial nuclear } \\
\text { power plants, 2) evaluation of the accuracy of direct assay techniques and computer code calculations for estimating/predicting } \\
\text { radionuclide inventories in retired reactors and neutron-activated components, 3) assessment of waste disposal options associated } \\
\text { with reactor decommissioning. } \\
\text { Direct assay technique, due to agreement with laboratory data lends confidence that the direct assay methodologies can provide } \\
\text { very accurate determination of the radionuclides inventories of SCRA and other types of highly neutron-activated metal wastes. } \\
\text { The information and databases that have been generated during these radionuclide characterization studies have provided a more } \\
\text { comprehensive and reliable assessment of radiological factors associated with the decommissioning of nuclear reactor power } \\
\text { stations. }\end{array}$ \\
\hline $\begin{array}{l}\text { Regulation } \\
\text { Manual for Conducting } \\
\text { Radiological Surveys in } \\
\text { Support of License } \\
\text { Termination } \\
\text { NUREG/CR-5849, ORAU- } \\
\text { 92/C57 }\end{array}$ & Berger, J.D. & $\begin{array}{l}\text { This manual, contains procedures for conducting radiological surveys during decommissioning, to demonstrate that residual } \\
\text { radioactive material satisfies release criteria (criteria which the NRC has determined to be environmentally acceptable). This } \\
\text { Manual is intend to provide instructions for performing survey procedures that will generate sound data to support a facility's license } \\
\text { termination. } \\
\text { Describe of the decommissioning process (in general), types and techniques of radiation survey's which are required during the } \\
\text { process. Provide general description of instrument types and requirements to them. Describe contention of documentation and } \\
\text { reports for final status surveys. } \\
\text { Conclusion: More appropriate for final status survey for decommissioning. }\end{array}$ \\
\hline $\begin{array}{l}\text { Research for Regulation } \\
\text { Residual Radionuclide } \\
\text { contamination within and } \\
\text { around commercial Nuclear } \\
\text { Power Plants } \\
\text { NUREG/CR-4289 } \\
\text { PNL-5429 }\end{array}$ & $\begin{array}{l}\text { K.H. Abel, D.E. } \\
\text { Robertson and } \\
\text { others }\end{array}$ & $\begin{array}{l}\text { The residual radionuclide concentrations, distributions and inventories at seven nuclear power plants (four shutdown and three } \\
\text { operating) have been investigated to provide a data base for use in formulating policies, strategies and guidelines for eventual } \\
\text { decommissioning of retired NPPs. This study has addressed radionuclides (both activation and fission products) transported from } \\
\text { the reactor pressure vessel and deposited in all other contaminated systems of each nuclear plant. This program was designed to } \\
\text { provide NRS with data base and decommissioning assessment of the residual radionuclide compositions, distributions, and } \\
\text { quantities at commercial nuclear generating stations. When the residual radionuclide inventory and compositions are better } \\
\text { defined more informed decisions can be made concerning the optimal decommissioning alternatives and methodologies, as well as } \\
\text { means for disposal of the generated wastes. }\end{array}$ \\
\hline $\begin{array}{l}\text { Regulation } \\
\text { Multi-Agency Radiation } \\
\text { Survey and Site Investigation } \\
\text { Manual (MARSSIM) } \\
\text { NUREG-1575 }\end{array}$ & $\begin{array}{l}\text { DOE, DOD, NRC, } \\
\text { EPA }\end{array}$ & $\begin{array}{l}\text { The MARSSIM provides detailed guidance for planning, implementing, and evaluating environmental and facility radiological } \\
\text { surveys conducted to demonstrate compliance with a dose- or risk-based regulation. In particular, MARSSIM describes generally } \\
\text { acceptable approaches for: } \\
\text { - planning and designing scoping, characterization, remediation-support, and final status surveys for sites with surface soil and } \\
\text { - Huilding surface contamination } \\
\text { - Historical Site Assessment (HSA) } \\
\text { - Quality Assurance (QA)/Quality Control (QC) in data acquisition and analysis } \\
\text { - fonducting surveys } \\
\text { - stat and laboratory methods and instrumentation, and interfacing with radiation laboratories } \\
\text { - documentation } \\
\text { With MARSSIM's main focus on final status surveys, this manual continues a process of following remediation activities that are } \\
\text { intended to remove below-surface contaminants. Therefore, some of the reasons for limiting the scope of the guidance to } \\
\text { contaminated surface soil and building surfaces include: 1) contamination is limited to these media for many sites following } \\
\text { remediation, 2) since many sites have surface soil and building surface contamination as the leading source of contamination, } \\
\text { existing computer models used for calculating the concentrations based on dose or risk generally consider only surface soils or } \\
\text { building surfaces as a source term, and } 3 \text { ) MARSSIM was written in support of cleanup rulemaking efforts for which supporting data } \\
\text { are mostly limited to contaminated surface soil and building surfaces. } \\
\text { However, the process of planning, implementing, assessing, and making decisions about a site described in MARSSIM } \\
\text { is applicable to all sites, even if the examples in this manual do not meet a site's specific objectives. }\end{array}$ \\
\hline
\end{tabular}




\begin{tabular}{|c|c|c|}
\hline $\begin{array}{r}\text { Title } \\
\end{array}$ & Authors & Abstract \\
\hline $\begin{array}{l}\text { Regulation } \\
\text { Radionuclide } \\
\text { Characterization of Reactor } \\
\text { Decommissioning Waste and } \\
\text { Neutron-Activated Metals } \\
\text { NUREG/CR-5894 } \\
\text { PNL-8106 }\end{array}$ & $\begin{array}{l}\text { D.E. Robertson } \\
\text { and others }\end{array}$ & $\begin{array}{l}\text { This study has been conducted to provide the NRC and licensees with a more comprehensive data base for regulatory assessment } \\
\text { of the radiological factors associated with reactor decommissioning and disposal of waste generated during these activities. This } \\
\text { study comprises two main research areas associated with reactor decommissioning: 1) providing a detailed radiological } \\
\text { characterization and assessment from the actual complete decommissioning of Shippingport Atomic Power Station and 2) } \\
\text { conducting a detailed radiological assessment of the highly neutron-activated metal components associated with reactor internals, } \\
\text { including spent fuel assembly hardware and spent control rods (direct assay methods). }\end{array}$ \\
\hline $\begin{array}{l}\text { Regulation } \\
\text { Monitoring for Compliance } \\
\text { With Decommissioning } \\
\text { Termination Survey Criteria } \\
\text { NUREG/CR-2082 } \\
\text { ORNL/HASRD-95 }\end{array}$ & $\begin{array}{l}\text { C.F. Holoway and } \\
\text { others }\end{array}$ & $\begin{array}{l}\text { This guide is designed as s general purpose document for those with concern for the final steps needed to ensure that a former } \\
\text { radiological site has been decontaminated to the point that it is safe to release that site for unrestricted public use. It is especially } \\
\text { designed for two parties: } \\
\text { 1) The licensee who wants to dispose of the site, and } \\
\text { 2) The regulatory agency inspector who wants to be sure that the site is (or is not) safe to release. } \\
\text { This guide is structured around the following objectives and procedures: } \\
\text { 1) Identification of monitoring requirements. } \\
\text { 2) General specifications for a monitoring program to ensure and confirm compliance. } \\
\text { 3) Development of a system of checks and audits. } \\
\text { 4) Application of monitoring program. }\end{array}$ \\
\hline $\begin{array}{l}\text { Regulation } \\
\text { Decommissioning Criteria for } \\
\text { Nuclear Facilities } \\
\text { 10CFR } 30.36,40.42,50.82 \text {, } \\
70.38,72.54\end{array}$ & NRC & $\begin{array}{l}\text { This rules set requirements to five major issues, namely: } \\
\text { - decommissioning alternatives. More than one alternatives method of decommissioning may be acceptable depending on the } \\
\text { type of radioactive contamination present at shutdown and other factors. Decommissioning alternatives are categorized into } \\
\text { three major classifications which are referred to as DECON, SAFSTOR, and ENTOMB. } \\
\text { timing. Each type of nuclear facility has characteristic radionuclides that will affect the selection of the decommissioning } \\
\text { alternative and the length of time acceptable to delay license termination. } \\
\text { - planning. Preliminary planning at the licensing stage and over facility life is important to ensure that decommissioning can be } \\
\text { accomplished safely. } \\
\text { financial assurance. The objective of this rule on financing the decommissioning of nuclear facilities is to require licensee to } \\
\text { provide reasonable assurance that adequate funds are available to ensure that decommissioning can be accomplished in a safe } \\
\text { manner and that lack of funds does not result in delays that may cause potential health and safety problems. } \\
\text { residual radioactivity. For all facilities covered by this rule, all premises must be suitable for release for unrestricted use before } \\
\text { a license can be terminated. To release property for unrestricted use a permissible level of residual activity must be established. }\end{array}$ \\
\hline $\begin{array}{l}\text { Regulation } \\
\text { Regulatory Guide } 1.86 \\
\text { Termination of Operating } \\
\text { Licenses for Nuclear } \\
\text { Reactors }\end{array}$ & $\begin{array}{l}\text { U.S. Atomic } \\
\text { Energy } \\
\text { Commission }\end{array}$ & $\begin{array}{l}\text { This guide describes general requirements to: } \\
\text { 1. Application for a license to possess but not operate (possession-only license). } \\
\text { 2. Alternatives for reactor retirement. } \\
\text { 3. Surveillance and security for the retirement alternatives whose final status requires a possession-only license. } \\
\text { 4. Decontamination for release for unrestricted use } \\
\text { 5. Reactor retirement procedures. } \\
\text { There is table "Acceptable surface contamination levels" for site assessing for release for unrestricted use. }\end{array}$ \\
\hline $\begin{array}{l}\text { Regulation } \\
\text { Standard Guide for Selection } \\
\text { and Use of Portable } \\
\text { Radiological Survey } \\
\text { Instruments for Performing in } \\
\text { Situ Radiological } \\
\text { Assessment in Support of } \\
\text { Decommissioning. } \\
\text { E 1893-97 }\end{array}$ & $\begin{array}{l}\text { ASTM Committee } \\
\text { E-10 on Nuclear } \\
\text { Technology and } \\
\text { Applications }\end{array}$ & $\begin{array}{l}\text { This standard provides recommendations on the selection and use of portable instrumentation that is responsive to levels of } \\
\text { radiation that are close to natural background. These instruments are employed to detect the presence of residual radioactivity that } \\
\text { is at, or below, the criteria for release from further regulatory control of a component to be salvaged or reused, or a surface } \\
\text { remaining at the conclusion of decontamination and/or decommissioning. } \\
\text { The choice of these instruments, their operating characteristics and the protocols by which they are calibrated and used will provide } \\
\text { adequate assurance that the measurements of the residual radioactivity meet the requirements established for release from further } \\
\text { regulatory control. } \\
\text { This standard is applicable to the in situ measurement of radioactive emissions that include: alpha, beta, gamma, characteristic } \\
\text { x-rays. }\end{array}$ \\
\hline
\end{tabular}




\begin{tabular}{|c|c|c|}
\hline Title & Authors & Abstract \\
\hline $\begin{array}{l}\text { Methodology } \\
\text { Alpha Detection for } \\
\text { Characterisation of D\&D } \\
\text { Sites. }\end{array}$ & $\begin{array}{l}\text { MacArthur, D.W., } \\
\text { Allander, K.S., } \\
\text { Koster, J., } \\
\text { Rawood-Sullivan, } \\
\text { M., Rojas, S. and } \\
\text { Sprouse, L. }\end{array}$ & $\begin{array}{l}\text { Objective: Detectors based on long-range alpha detector (LRAD) technology are useful during the assessment phase of D\&D. } \\
\text { ALARD detecting the ion pairs produced by an alpha particle's interaction with air rather then the particles themselves. Two types } \\
\text { of monitors based on this technology are an airflow system, where an air current (generated by fans) transports the ions to the ion } \\
\text { detector (possible for detection in the straight and distorted pipes), and an electrostatic designed, where an electric field attracts the } \\
\text { ions to the ion detector (possible for detection of the concrete surfaces). } \\
\text { Technology provider: LANL } \\
\text { Time required to take one measurement: Assay of the items can be done quickly without analytical delays. } \\
\text { Complexity: } \\
\text { NDA ability: + } \\
\text { Performance: lon pairs have a measured lifetime of } ~ \\
\text { meters) than the alpha particle ( }-3 \mathrm{~cm} \text { ). Because the ions have a long range, a single detector can monitor all contamination } \\
\text { present on an object in a single measurement. The measured sensitivity of the concrete monitor is expected to be } 10 \text { dis/min per } \\
100 \mathrm{~cm} 2 \text { and for the pipes from } 50 \text { to } 100 \text { dis/min total contamination. } \\
\text { Cost: } \\
\text { Experience of applying: }\end{array}$ \\
\hline $\begin{array}{l}\text { Techniques } \\
\text { Study of Alpha } \\
\text { Characterrization of a D\&D } \\
\text { Site Using Long-Range } \\
\text { Alpha Detectors. }\end{array}$ & $\begin{array}{l}\text { Rawool-Sullivan, } \\
\text { M.W., Allander, } \\
\text { K.S., Bounds, J.A., } \\
\text { Koster, J.E., } \\
\text { MacArthur, D.W., } \\
\text { Sprouse, L., Stout, } \\
\text { D., Vaccarella, J.A. } \\
\text { and Vu, T.Q. }\end{array}$ & $\begin{array}{l}\text { Objective: This article describes the specialties of the systems based on the long-range alpha detection (LRAD) technology, and } \\
\text { includes items; } \\
\text { - General information } \\
\text { - Surface monitors } \\
\quad \text { - Alpha monitoring results on concrete } \\
\text { - Measurement of contamination on stainless steel table top } \\
\text { - Internal volume monitor } \\
\quad \text { - Pipe monitor } \\
\quad \text { - Glove box monitor } \\
\text { LRAD systems are applicable in various aspects and phases of D\&D efforts. With further development these detectors could } \\
\text { provide cost-effective, rugged, non-destructive and in situ monitoring of alpha contamination for D\&D purposes. } \\
\text { Technology provider: LANL } \\
\text { Time required to for one measurement: real time } \\
\text { Complexity of the instrument: } \\
\text { NDA ability: + } \\
\text { Performance: } \\
\text { Cost: } \\
\text { Experience of applying: }\end{array}$ \\
\hline $\begin{array}{l}\text { Techniques } \\
\text { Alpha Detection for } \\
\text { Decontamination and } \\
\text { Decommissioning: } \\
\text { Results and Possibilities }\end{array}$ & MacArthur, D.W. & $\begin{array}{l}\text { Objective: This article contains information concerning the long-range alpha detection (LRAD) technology detectors. Three } \\
\text { monitors of particular interest in D\&D operations are the building surface monitor, the internal volume monitor for use on the inner } \\
\text { surfaces of pipes, ducts, and tanks, and the conveyer belt monitor for concrete rubble and structural steel. } \\
\text { Technology provider: LANL } \\
\text { Time required to for one measurement: Real time } \\
\text { Complexity of the instrument: There are no thin windows, fine wires, or sensitive electronics enabling true in-situ operation with } \\
\text { good reliability } \\
\text { NDA ability: }+ \\
\text { Performance: LRAD-based sensors have been built with } 10-d p m / 100 \mathrm{~cm} 2 \text { surface sensitivity, } 50 \text {-dpm spot sensitivity, and } 0.1 \mathrm{pCi/l} \\
\text { radon sensitivity } \\
\text { Cost: } \\
\text { Experience of applying: Surface monitors have been used extensively, both in laboratory and field environments, internal volume } \\
\text { monitors have been tested in the laboratory, and the conveyer system is still a conceptual design. }\end{array}$ \\
\hline
\end{tabular}




\begin{tabular}{|c|c|c|}
\hline Title & Authors & Abstract \\
\hline $\begin{array}{l}\text { Instrument } \\
\text { Alpha Characterization of } \\
\text { Concrete Surfaces at } \\
\text { Decontamination \& } \\
\text { Decommissioning (D\&D) } \\
\text { Sites }\end{array}$ & $\begin{array}{l}\text { Vu, T.Q., Rawool- } \\
\text { Sullivan, M.W., } \\
\text { Koster, J., } \\
\text { Stout, D., and } \\
\text { Beasinger, A. }\end{array}$ & $\begin{array}{l}\text { Objective: The concrete surface monitor (CSM) developed at Los Alamos National Laboratory (LANL) supports both } \\
\text { characterization and waste minimization efforts at D\&D sites containing large concrete surfaces and structures of different forms } \\
\text { and shapes. The CSM is based on the electrostatic Long-Range Alpha Detector (LRAD). The reading can be sent to a portable } \\
\text { computer or read out directly on a portable oscilloscope for a visual interpretation. There are two types of surface monitors: } 2500 \\
\text { cm2 ( } 50 \times 50 \times 10 \mathrm{~cm} \text { ) includes background subtraction technology while the } 300 \mathrm{~cm} 2 \text { ( } 27 \times 11 \times 10 \mathrm{~cm} \text { ), and } 1431 \mathrm{~cm} 2 \mathrm{CSMs} \text { do not. } \\
\text { These instruments give opportunity to monitor large surface areas with a single measurement. } \\
\text { Technology provider: Los Alamos National Laboratory (LANL) } \\
\text { Time required to for one measurement: Real time } \\
\text { Complexity of the instrument: CSM LARD detector includes the sensitive electrometer developed by Guy Arnon at LANL } \\
\text { specifically for LRAD detectors. } \\
\text { NDA ability: + } \\
\text { Performance: The response time for CSM's is between } 30 \text { and } 120 \text { seconds per reading depending on the strenght of the } \\
\text { contamination. The sensitivity of the } 300 \mathrm{~cm} 2 \text { CSM is } 7.1 \text { dpm/fA. The sensitivity of other CSMs ranges from } 5.5 \text { to } 7.1 \text { dpm/fA. } \\
\text { Cost: } \\
\text { Experience of applying: On July } 15,1994, \text { the first generation CSM was used to measure the residual alpha contamination on } \\
\text { concrete blocks which came out of trenches at Technical Area-21 (TA-21) at LANL. }\end{array}$ \\
\hline $\begin{array}{l}\text { Instrument } \\
\text { Alpha Contamination } \\
\text { Assessment for D\&D } \\
\text { Activities: Monitoring Inside } \\
\text { Glove Boxes and Vessels }\end{array}$ & $\begin{array}{l}\text { Rawool-Sullivan, } \\
\text { M.W., Bolton, R.D., } \\
\text { Conaway, J.G. and } \\
\text { MacArthur, D.W. }\end{array}$ & $\begin{array}{l}\text { Objective: A new approach to glove box monitoring have been developed. It involves drawing air out of one glove port through a } \\
\text { detection grid that collects ions created in the air inside the glove box by ionizing radiation, especially alpha radiation. This device } \\
\text { uses LRAD technology, the monitor is similar to those used in investigating pipe contamination. This instrument can be used not } \\
\text { only for glove box measurement but for other enclosed volumes. } \\
\text { Technology provider: Los Alamos National Laboratory } \\
\text { Time required to for one measurement: Real time } \\
\text { Complexity of the instrument: Device consist of fan, detector and air duct. } \\
\text { NDA ability: }+ \\
\text { Performance: } 0.001 \mathrm{nCi} / \mathrm{g}-7 \mathrm{nCi} / \mathrm{g} \text { depends on the conditions } \\
\text { Cost: } \\
\text { Experience of applying: }\end{array}$ \\
\hline $\begin{array}{l}\text { Methodology, Instrument } \\
\text { Detection of Contaminants in } \\
\text { Concrete Surfaces Using } \\
\text { Prompt Gamma Neutron } \\
\text { Activation Analysis. }\end{array}$ & $\begin{array}{l}\text { Dulloo, A.R., } \\
\text { Congedo, T.V., } \\
\text { Ruddy, F.H., } \\
\text { Seidel, J.G., } \\
\text { Williams, R.P., and } \\
\text { Weigle, D.H. }\end{array}$ & $\begin{array}{l}\text { Objective: Prompt Gamma Neutron Activation Analysis (PGNAA) is an method for the characterization of contaminants with } \\
\text { suitable nuclear characteristics (e.g. mercury and cadmium). N-SCAN system is using this method and is able to characterize the } \\
\text { contaminants located at or near the surface of floors and walls. } \\
\text { Technology provider: Westinghouse Science \& Technology Center } \\
\text { Time required for one measurement: real time } \\
\text { Complexity: The main components of the Westinghouse system are an electronic deuterium-tritium neutron generator, a hight- } \\
\text { purity germanium gamma detector, a sodium iodide (thallium-activated) annulus used in anticoincidence mode for Compton } \\
\text { suppression, and a computer-controlled acquisition interface module. This system can be adapted to characterization applications } \\
\text { such as drum assaying and surveying of construction debris from D\&D activities. } \\
\text { NDA ability: + } \\
\text { Performance: The system is able to detect small amounts of contaminants in the near-surface region of concrete (0 to } 3 \text { in. deep). } \\
\text { Cost: } \\
\text { Experience of applying: This system has already been utilizèd during testing at Westinghouse to detect trace quantities of } \\
\text { hazardous elements in soil and to perform real-time identification of simulants of chemical weapons agents in munitions. }\end{array}$ \\
\hline
\end{tabular}




\begin{tabular}{|c|c|c|}
\hline Title & Authors & $\begin{array}{ll}\text { Abstract } \\
\end{array}$ \\
\hline $\begin{array}{l}\text { Instrument } \\
\text { Evaluation of a Low } \\
\text { Background Proportional } \\
\text { Counter for Detection of High } \\
\text { Energy Beta Particles with } \\
\text { Application to [sup 90] } \mathrm{Sr} \\
\text { Surface. }\end{array}$ & $\begin{array}{l}\text { Islam, K.T.S., } \\
\text { Johnson, L., Brey, } \\
\text { R.R., Gesell, T.F. } \\
\text { and Mclsaac, C. }\end{array}$ & $\begin{array}{l}\text { Objective: Conventional radiochemical methods used to quantify } 90 \mathrm{Sr} \text { are complicated and time-consuming. A relatively simple, } \\
\text { inexpensive instrument has been developed for analysis of high energy beta surface contamination in the presence of lower energy } \\
\text { beta emitters. The instrument detects beta particals from } 90 \mathrm{Y} \text {, which is in secular equilibrium with } 90 \mathrm{Sr} \text {. The instrument is } \\
\text { expected to have application in decontamination and decommissioning, decisions concerning release of materials, and waste } \\
\text { management. } \\
\text { Technology provider: Idaho State University, Department of Physics/Health Phisics, Campus Box } 8106 \text {, Pocatello, ID } 83209 \text {; } \\
\text { Lockheed ldaho Technologies Company, P.O. Box 1625, Idaho Falls, ID } 83415 ; \\
\text { Time required for one measurement: } \\
\text { Complexity: The instrument consist of three stacked gas-flow proportional detectors. The bottom two are operated in coincidence } \\
\text { mode and the top detector is operated in anti-coincidence to the others for reducing cosmic-ray background. } \\
\text { NDA ability: }+ \\
\text { Performance: The thickness of the bottom two counters eliminates beta particals with energies below } 660 \mathrm{keV} \text { from the second } \\
\text { detector. The end-point energy of the } 90 \mathrm{Sr} \text { beta is } 546 \mathrm{KeV} \text {, while that for } 90 \mathrm{Y} \text { is } 2.28 \mathrm{MeV} \text {. Greater than } 69 \% \text { of the particles } \\
\text { emitted during the decay of } 90 \mathrm{Y} \text { have energies above the end-point energy of } 90 \mathrm{Sr} \text {. } \\
\text { Cost: } \\
\text { Experience of applying: }\end{array}$ \\
\hline $\begin{array}{l}\text { Instrument } \\
\text { A Flexible, Self-Contained } \\
\text { Germanium Spectrometer for } \\
\text { the In-Situ Measurment of } \\
\text { Gamma-Ray Emitting } \\
\text { Radionuclides In and Around } \\
\text { Piping. }\end{array}$ & \begin{tabular}{|l} 
Lepel, E.A., \\
Brodzinski, R.L., \\
Reeves, J.H. and \\
Kohli, R. \\
\end{tabular} & $\begin{array}{l}\text { Objective: A 4.83-cm diameter modular probe consisting of a liquid nitrogen reservoir, a preamplifier, and a high-resolution } \\
\text { germanium gamma-ray spectrometer with flexible connections between the modules has been developed for the measurement of } \\
\text { gamma rays in and around piping. The assembly is sufficiently flexible to navigate through a "3-inch diameter p-trap". } \\
\text { Approximately } 23 \mathrm{~m} \text { (75 ft) of signal, detector bias, preamplifier, and detector temperature cables were in closed in a flexible plastic } \\
\text { sheath for connecting to the multi-channel analyzer which is a computer controlled commercial NOMAD PLUS system. NOMAD } \\
\text { PLUS is a small suitcase that contains the detector bias supply, amplifier, and ADC and sends its data to a computer through its } \\
\text { parallel port. } \\
\text { Technology provider: PNNL + Battelle Columbus Laboratories } \\
\text { Time required to for one measurement: The detector specifications required a cooling time of } 4 \text { hours before detector can be } \\
\text { used. Once cooled, the detector could then be used with bias on for at least two hours after being completely filled with liquid } \\
\text { nitrogen. } \\
\text { Complexity: } \\
\text { NDA ability: + } \\
\text { Performance: Using the spectra obtained from the potassium calibration, minimum detectable activities (MDA) at } 90 \% \text { confidence } \\
\text { limit can be calculated for a number of fission/activation products and actinides. Some of them are listed in the article. } \\
\text { Cost: } \\
\text { Experience of applying: The detector was successfully demonstrated by lowering down a "long-leg" sample tube next to a } 235 \mathrm{U} \\
\text { enriched fuel rod assembly. }\end{array}$ \\
\hline
\end{tabular}




\begin{tabular}{|c|c|c|}
\hline Title & Authors & Abstract \\
\hline $\begin{array}{l}\text { Instrument } \\
\text { Pipe Explorer [sup } \\
\text { (trademark)] System. } \\
\text { Innovative Technology } \\
\text { Summary Report. }\end{array}$ & $\begin{array}{l}\text { Oak Ridge } \\
\text { National } \\
\text { Laboratory }\end{array}$ & $\begin{array}{l}\text { Objective: The Pipe Explorer System (PES) has been used to transport various characterizing sensors into piping systems that } \\
\text { have been radiologically contaminated. PES can be deployed through constructions in the pipe, around } 90 \text { degrees bends, } \\
\text { vertically up and down, and in slippery conditions. Because the detector is transported inside the membrane, which is inexpensive } \\
\text { and disposable, it is protected from contamination, which eliminates cross-contamination and false readings. The system is } \\
\text { capable of deploying in pipes as small as } 2 \text {-in. diameter and up to } 250 \text {-ft long. The PES is now available as a commercial service } \\
\text { for gamma, beta, and video surveys. Alpha measurement capability has been developed and will be demonstrated soon. The } \\
\text { ideal location for application of the PES is pipes under buildings or in hard to access areas. } \\
\text { Technology provider: Science and Engineering Associates, Inc (SEA) } \\
\text { Time required to for one measurement: System includes the capability for motorized deployment and deployment control, } \\
\text { automated distance tracking, and integration of the detector output signal as a function for distance for real-time data tracking. } \\
\text { Complexity: The heart of the system is an air-tight membrane, which is initially spooled inside the canister. When the canister is } \\
\text { pressurized, the membrane inverts and deploys inside the pipe. A two-man crew is usually mobilized. } \\
\text { NDA ability: + } \\
\text { Performance: Beta contamination measurements showed that hand survey readings were lower than the actual measurements } \\
\text { taken inside the pipe. Deployment accuracy was determine to be } 5 \% \text {. } \\
\text { Cost: SEA anticipates the current \$28/ft deployment cost will drop to about } 11 \$ / \text { th. } \\
\text { Experlence of applying: To date the PES has been successfully demonstrated at three sites: the Formerly Utilized Sites Remedial } \\
\text { Action Program (FUSRAP) site in Adrian, Michagan, a DOE site in Albuquerque, New Mexico, and the Grand Junction Project } \\
\text { Office in Colorado. } \\
\text { Contacts: Steve Bossart, Project Manager, U.S. DOE (304) } 285-4643 \text {; Jerry Hyde, Program Manager, U.S. DOE (301) 903-7914 }\end{array}$ \\
\hline $\begin{array}{l}\text { Instrument } \\
\text { Laboratory Evaluation of the } \\
\text { Pipe Explorer Gamma } \\
\text { Measurement and } \\
\text { Deployment Capability }\end{array}$ & $\begin{array}{l}\text { Cremer C.D., } \\
\text { Cramer, E. and } \\
\text { Lowry, W. }\end{array}$ & $\begin{array}{l}\text { Objective: Article contains results of laboratory assay of the Pipe Explorer System (PES). The assay items are: } \\
\text { Lab scale tests of the deployment system. } \\
\text { - Membrane test } \\
\text { - Deployment test } \\
\text { - Lab scale test summary } \\
\text { Radiation detection } \\
\text { - Gamma radiation detection system } \\
\text { - Minimum detectable activities } \\
\text { - Gamma detection inside 2-inch pipe } \\
\text { - Laboratory test of detection capability } \\
\text { - Summary of the performance and improvements to the detection system } \\
\text { Technology provider: Science and Engineering Associates, Inc (SEA) } \\
\text { Detailed information see previous article. }\end{array}$ \\
\hline
\end{tabular}




\begin{tabular}{|c|c|c|}
\hline Title & Authors & Abstract \\
\hline $\begin{array}{l}\text { Monitoring of Surface Alpha } \\
\text { Contamination with } \\
\text { Expensive Passive Monitors }\end{array}$ & \begin{tabular}{|l|} 
Gammage, R.B., \\
DePriest, J.C., \\
Wheeler, R.V., \\
Dempsey, J.C. and \\
Kotrappa, P. \\
\\
\end{tabular} & $\begin{array}{l}\text { Objective: Field applications are presented in the monitoring of indoor and outdoor surface alpha contamination using passive } \\
\text { devices. The alpha track detector (ARD) and electric device are two new approaches for the inexpensive, sensitive and accurate } \\
\text { detection of surface alpha contamination that will meet some currently unfilled needs in decontamination and decommissioning. } \\
\text { Passive measurements are described for fixed contamination on floors and equipment as well as measurements of plutonium in } \\
\text { soil. } \\
\text { Technology provider: Oak Ridge National Laboratory, Health and Safety Research Division } \\
\text { Time required to for one measurement: The electric device has the advantage of following readout immediately after exposure } \\
\text { using a portable voltmeter. Processing of the exposed plastic track detector requires chemical etching. } \\
\text { Complexity of the instrument: } \\
\text { NDA ability: } \\
\text { Performance: Sensitivity is such that passive measurements made in on or two hours produce } 10: 1 \text { signal-to-noise readings at a } \\
\text { proposed release level of } 220 d p m / 100 \mathrm{~cm} 2 \text { (3.7Bq/cm2). The small alpha track detectors can be deployed in cracks, under doors, } \\
\text { inside narrow pipes and other difficult to access locations where contaminated dirt collects and resists easy removal. Examples are } \\
\text { given of the mapping. The track detectors can also provide spatially resolved information on a fine scale and recognize micron- } \\
\text { sized particulate contamination. } \\
\text { Cost: } \\
\text { Experience of applying: Each type of device was calibrated with a Pu-239 heck source. The passive devices were also evaluated } \\
\text { in the monitoring of soils contaminated with plutonium that were obtained from the U.S. Department of Energy, Nevada Test Site } \\
\text { (NTS). }\end{array}$ \\
\hline $\begin{array}{l}\text { Radiometric Tools for } \\
\text { Decommissioning }\end{array}$ & $\begin{array}{l}\text { Ronaldson, J.P. } \\
\text { and Orr, C.H. }\end{array}$ & $\begin{array}{l}\text { Objective: The experience of using the RadScan } 600 \text { in the process of three plutonium oxide/uranium oxide facilities } \\
\text { decommissioning in Sellafield reprocessing plant, Nothwest o England. Totally } 60 \text { glove boxes and vessels were utilized. } \\
\text { RadScan } 600 \text { was used to provide prior assessment of contamination level. This system combines visual and radionetric surveys } \\
\text { of individual gloveboxes or entire process lines. This detectional gamma count rate meter uses inorganic scintillator technology } \\
\text { and spectroscopy electronics to select regions in the gamma spectra which match the emitted energies from the radionuclides of } \\
\text { interest. To control Pu concentration DISPIM (decom in-situ Pu inventory monitor) - a system for total plutonium assay by passive } \\
\text { neutron coincidence counting using independent neutron detector "modules" deployed around the available surfaces of each } \\
\text { glovebox. } \\
\text { Conclusion: This family of radiometric tools described in this article have been an integral part of BNFL's plutonium facility } \\
\text { decommissioning operations for several years. The information provided by these systems has allowed decommissioning } \\
\text { managers and engineers to successfully plan and execute extensive programs within redundant plutonium facilities. } \\
\text { Technology provider: BNFL instruments Ltd. } \\
\text { Time required to for one measurement: } \\
\text { Complexity of the instrument: } \\
\text { NDA ability: } \\
\text { Performance: } \\
\text { Cost: } \\
\text { Experience of applying: }\end{array}$ \\
\hline
\end{tabular}




\begin{tabular}{|c|c|c|}
\hline Title & Authors & Abstract \\
\hline $\begin{array}{l}\text { Spectrometric Techniques for } \\
\text { the Measurement of } \\
\text { Radioactive Contamination in } \\
\text { Buildings }\end{array}$ & $\begin{array}{l}\text { Miller, K.M., } \\
\text { Reginatto, M., } \\
\text { Shebell, P., } \\
\text { Klemic, G.A. and } \\
\text { Gogolak, C.V. }\end{array}$ & $\begin{array}{l}\text { Objective: The use of direct photon counting to identify and quantify radionuclides at a measurement site has been well } \\
\text { established. While this technique, commonly known as in situ spectrometry has generally been applied to the outdoor } \\
\text { environment, in principle, it can be applied to the measurements of the radiation fission inside buildings as well. The main } \\
\text { difference is that the source distribution is generally more complex in doors due to varied building materials as compared to outdoor } \\
\text { where soil is frequently the only medium to consider. In today's era of decontamination and decommissioning of nuclear facilities, } \\
\text { the ability to perform nuclide specific measurements of radioactive contamination provides a rapid and sensitive component to a } \\
\text { radiological survey plan, particularly where gross radiation measurement techniques lack the requisite sensitivity to demonstrate a } \\
\text { release criteria have been met. The article describes the following measurement techniques: } \\
\text { Exposure Rate Measurements } \\
\text { Peak Analysis } \\
\text { - Primary Photon Component } \\
\text { - Primary and Scattered Components } \\
\text { Continuum Analysis } \\
\text { - Total Spectrum Stripping } \\
\text { - Partial Spectrum Stripping } \\
\text { Surface Activity and Concentration Measurements } \\
\text { Measurement on a Grid } \\
\text { Conclusions: The spectrometric-based methodologies in this paper indicate that sensitive nuclide-specific measurements can be } \\
\text { performed in the indoor environment. However, with certain simple models and the redundancy of measurement checks with the } \\
\text { various methods, it appears that the uncertainties are within reason and would not pose a limiting factor for release survey } \\
\text { measurements. } \\
\text { Technology provider: Environmental Measurements Laboratory, U.S. Department of Energy } \\
\text { Time required to for one measurement: } \\
\text { Complexity of the instrument: } \\
\text { NDA ability: } \\
\text { Performance: } \\
\text { Cost: } \\
\text { Experience of applying: }\end{array}$ \\
\hline
\end{tabular}


Title

\section{A Gamma Scanner for Pre-}

and Waste Segregation

Authors

Mottershead, G.

(

\begin{tabular}{|l|l} 
& \\
& \\
& \\
\hline Key Issues in the Planning & Manion, W.J. \\
for Commercial Reactor
\end{tabular}

for Commercial Reactor

Decommissioning

\section{Abstract}

Objective: A gamma scanning measurement system has been developed which combines CCD camera and gamma detection technologies into an integral head capable of performing simultaneous visual and radiometric scan of contaminated nuclear plant area. Deployment and operation of measurement system can be carried out remotely and in both manual or pre-programmed scanned models. This system has immediate applications for preliminary surveys prior to clean-out and decontamination operations in order to aid the planning of decommissioning operations. The in situ identification and segregation of radiation hot spots will minimize cross-contamination onto clean materials.

Technology provider: BNFL

Time required to for one measurement: Real time

Complexity of the instrument: Csesium iodide with thallium CsI(TI) detector. The Video Overlay system combines the graphics generated by the computer with the video signal from the color camera. It is then connected to an integrated LCD color monitor and VHS video recorder (VCR)

NDA ability: +

Performance:

Dynamic range of $<1 \mathrm{mSv} / \mathrm{hr}$ to $1 \mathrm{~Sv} / \mathrm{hr}$ (up to $20 \mathrm{kps}$ through the detector system).

- Working distance from head to source of up to $10 \mathrm{~m}$.

- Field of View (FOV) selectable between 5 and 10.

- Operator to be able to perform the scan up to $30 \mathrm{~m}$ away from the head.

- System capable of detecting gamma sources in the range $100 \mathrm{keV}$ to $>1 \mathrm{MeV}$.

- Signal to background ratio of 10:1 at $662 \mathrm{keV}$.

- Ability to display and store gamma spectrometry data.

- A permanent color video recording of each can with overlaid radiometric field of view, count rate and positional data.

- All equipment to e rugged and transportable.

Cost:

Experience of applying:

Conclusions: This article is probably telling about the later BNFL RadSan 600 model.

Objective: The process of decommissioning a nuclear facility is quite straightforward from an execution standpoint. The physical acts of decontamination, removal of activated equipment and materials, followed by the removal of supporting systems and

structures lend themselves to a very simple critical path with the opportunity for many parallel decommissioning activities involving systems and structures that are non-essential to the critical path. Unfortunately, the actual process of decommissioning is the only thing about the topic that is straightforward. The process of planning for decommissioning is fraught with pitfalls. The causes

include: The impact of the high level waste repository debacle. The impact of regional low level waste disposal sites. The impact of FERC and state public utility commissions on the allowable end product of decommissioning as well as the magnitude of allowable costs. 1988 NRC regulations on the allowable level of decommissioning costs. The specific effects of these causative factors are discussed in the paper.

Technology provider: Nuclear Energy Systems, Danbury, Connecticut

Time required to for one measurement:

Complexity of the instrument:

NDA ability:

Performance:

Cost:

Experience of applying:

Conclusions: The article is useful for planning the decommissioning activities at the America reactors. The results described in it can be used while developing the Ukrainian Regulations for the D\&D. 


\begin{tabular}{|c|c|c|}
\hline Title & Authors & Abstract \\
\hline $\begin{array}{l}\text { Locating Those Hard-To-Find } \\
\text { "Hot Spots" }\end{array}$ & $\begin{array}{l}\text { Hughes, K.A. and } \\
\text { Lightfoot, J.A. }\end{array}$ & $\begin{array}{l}\text { Objective: The article describes the gamma scanner RadScan } 600 \text {. RadScan } 6000 \text { is suitable for any application where an area } \\
\text { survey of the radioactive material in a building or facility is required. In any typical application such as surveying a high active fuel } \\
\text { handling cell, the RadScan } 600 \text { will be mechanically transported and positioned in the cell. The operator, sitting at the control } \\
\text { conclose outside the cell, can then conduct the survey sequence or initiate an automatic scan. The instrument was developed } \\
\text { particularly to aid decommissioning and clean-up teams, and can be used for a number of purpose, including: } \\
\text { - Assessing the contribution of any individual hotspot to an overall dose rate. } \\
\text { - Monitoring the success of clean-up operations. } \\
\text { - Aiding in the design of shielding. } \\
\text { - Locating radiation sources in high dose rate environments. } \\
\text { - Identifying the radioisotopes present within an environment. } \\
\text { Technology provider: BNFL } \\
\text { Time required to for one measurement: Real time } \\
\text { Complexity of the instrument: } \\
\text { NDA ability: }+ \\
\text { Performance: The caeium iodide spectrometer, located within a highly collimating tungten shield can detect gamma rays with } \\
\text { energies between } 100 \text { keV and } 10 \text { MeV. The response of the system to } 662 \text { keV radiation from a point source of Cs-137 is } \\
\text { symmetrical about its center point. The device has a nominal field-of-view of } 4 \text { degrees, though it can be changed mechanically to } \\
2 \text { or } 9 \text { degrees depending upon the resolution required or a particular application. } \\
\text { Cost: } \\
\text { Experience of applying: The device has been used to monitor the location of contamination contained in a number of facilities } \\
\text { which are to be decommissioned or need extensive decontamination work, such as contaminated buildings at Sellafield, highly } \\
\text { active cells used for PIE at Winfrith, and inside the Windscale piles. }\end{array}$ \\
\hline $\begin{array}{l}\text { Development of Sampling } \\
\text { Methodic of Radioactive } \\
\text { Materials and Measurements } \\
\text { in Performing Radioactive } \\
\text { inspection of APS. }\end{array}$ & $\begin{array}{l}\text { Matusevish, E.S. } \\
\text { and Cherkashin, } \\
\text { V.A. }\end{array}$ & $\begin{array}{l}\text { Objective: The article describes various methods of activity measurements dependent on the type of a surface, its activity, activity } \\
\text { distribution within the material. } \\
\text { Technology provider: Obninsk Institute of Nuclear Power Engineering } \\
\text { Time required to for one measurement: } \\
\text { Complexity of the instrument: } \\
\text { NDA ability: } \\
\text { Performance: } \\
\text { Cost: } \\
\text { Experience of applying: } \\
\text { Conclusions: The article doesn't contain any specific methodology of radiological survey. It contains only the recommendations } \\
\text { for applying these very technologies for different equipment, surfaces, etc. The article is useful or planing the radiological survey } \\
\text { activities. }\end{array}$ \\
\hline $\begin{array}{l}\text { Survey of Estimation } \\
\text { Methods for Radioactive } \\
\text { Inventory in Nuclear } \\
\text { Reactors to be } \\
\text { Decommissioned. }\end{array}$ & Ezure, $H$. & $\begin{array}{l}\text { Objective: In the nuclear reactors to be decommissioned, radioactive inventories due to neutron activation are calculated using } \\
\text { application codes and cross section libraries. Some of them are evaluated through benhmark tests. This review surveys the } \\
\text { present situation and problem of the calculation methods together with the measurement on radioactive inventories and chemical } \\
\text { composition analyses of reactor components. } \\
\text { Technology provider: Nippon Advanced Information Service } \\
\text { Time required to for one measurement: } \\
\text { Complexity of the instrument: } \\
\text { NDA ability: } \\
\text { Performance: } \\
\text { Cost: } \\
\text { Experience of applying: } \\
\text { Conclusions: The present situation and problems of the calculation methods together with the measurements of radioactive } \\
\text { inventories were surveyed. }\end{array}$ \\
\hline
\end{tabular}




\section{APPENDIX B. RESULTS OF CHARLES THOMAS' RADIOLOGICAL INVESTIGATION OF TWO GRAPHITE REACTORS}

Table B-1 Elemental Concentrations (in ppm) in Two Graphite Reactors

\begin{tabular}{|l|c|c|}
\hline & $\begin{array}{c}\text { C Graphite } \\
\text { (U.S. Reactor) }\end{array}$ & $\begin{array}{c}\text { G-2 Graphite } \\
\text { (French Reactor) }\end{array}$ \\
\hline Total Ash & 10 & 220 \\
\hline Barium & .007 & $\mathrm{~nm}$ \\
\hline Boron & .10 & .20 \\
\hline Calcium & 0.22 & 30.0 \\
\hline Chlorine & 7.8 & 3.5 \\
\hline Chromium & .003 & $\mathrm{~nm}$ \\
\hline Dysprosium & $<0.001$ & 0.010 \\
\hline Europium & $\mathrm{nm}$ & 0.0007 \\
\hline Iron & 0.19 & 2.0 \\
\hline Lithium & 0.003 & $\mathrm{~nm}$ \\
\hline Samarium & $<0.01$ & 0.017 \\
\hline Strontium & 0.002 & $\mathrm{~nm}$ \\
\hline Titanium & 0.001 & 5.0 \\
\hline Vanadium & 0.015 & 32.0 \\
\hline
\end{tabular}

$\mathrm{nm}=$ not measured by technique used.

Table B-2 Radionuclide Concentration in Reactor Graphite

\begin{tabular}{|l|c|c|}
\hline \multicolumn{1}{|c|}{ Isotope } & \multicolumn{2}{|c|}{ Concentration (pCi/gram) } \\
\hline & C-Reactor & French Reactor \\
\hline${ }^{14} \mathrm{C}$ & $8,264,000(10 \%)$ & 987,000 \\
\hline${ }^{36} \mathrm{Cl}$ & $58120(5 \%)$ & $41690(5 \%)$ \\
\hline${ }^{60} \mathrm{Co}$ & $81840(4.3 \%)$ & $130300(4 \%)$ \\
\hline${ }^{90} \mathrm{Sr}$ & $19840(10 \%)$ & $<2400$ \\
\hline${ }^{133} \mathrm{Ba}$ & $18090(3 \%)$ & $4194(4 \%)$ \\
${ }^{137} \mathrm{Cs}$ & $25650(4 \%)$ & $4169(4 \%)$ \\
\hline${ }^{151} \mathrm{Sm}$ & --- & --- \\
\hline${ }^{152} \mathrm{Eu}$ & $<250$ & $<320$ \\
\hline${ }^{154} \mathrm{Eu}$ & $5413(4 \%)$ & $15450(2 \%)$ \\
\hline${ }^{155} \mathrm{Eu}$ & $6289(7 \%)$ & $5610(7 \%)$ \\
\hline${ }^{*} \mathrm{Alpha}$ & 6289 & 493 \\
\hline
\end{tabular}

*Based on $3.46 \mathrm{mg} / \mathrm{cm}$ range for alpha particles 
APPENDIX C. RADIATION DETECTORS AND SYSTEMS

Table C-1 Radiation Detectors with Applications to Gamma Surveys

\begin{tabular}{|c|c|c|c|}
\hline Detector Type & Detector Description & Application & Remarks \\
\hline Gas Ionization & $\begin{array}{l}\text { Pressurized ionization } \\
\text { chamber; Non-pressurized } \\
\text { ionization chamber }\end{array}$ & Exposure rate measurements & \\
\hline Geiger-Mueller & $\begin{array}{l}\text { Pancake }\left(<2 \mathrm{mg} / \mathrm{cm}^{2}\right. \\
\text { window) or side window } \\
\left(\sim 30 \mathrm{mg} / \mathrm{cm}^{2}\right)\end{array}$ & $\begin{array}{l}\text { Surface scanning; exposure } \\
\text { rate correlation (side } \\
\text { window in closed position) }\end{array}$ & $\begin{array}{l}\text { Low relative sensitivity } \\
\text { to gamma radiation }\end{array}$ \\
\hline \multirow[t]{4}{*}{ Scintillation } & $\begin{array}{l}\mathrm{NaI}(\mathrm{T} 1) \text { scintillator; up to } 5 \\
\mathrm{~cm} \text { by } 5 \mathrm{~cm}\end{array}$ & $\begin{array}{l}\text { Surface scanning; exposure } \\
\text { rate correlation }\end{array}$ & $\begin{array}{l}\text { High sensitivity; cross } \\
\text { calibrate with PIC (or } \\
\text { equivalent) or for } \\
\text { specific site gamma } \\
\text { energy mixture for } \\
\text { exposure rate } \\
\text { measurements. }\end{array}$ \\
\hline & $\begin{array}{l}\mathrm{NaI}(\mathrm{T} 1) \text { scintillator; large } \\
\text { volume and "well" } \\
\text { configurations }\end{array}$ & $\begin{array}{l}\text { Laboratory gamma } \\
\text { spectrometry }\end{array}$ & \\
\hline & $\begin{array}{l}\text { CsI or } \mathrm{NaI}(\mathrm{T} 1) \text { scintillator; } \\
\text { thin crystal }\end{array}$ & $\begin{array}{l}\text { Scanning; low-energy } \\
\text { gamma and } x \text {-rays }\end{array}$ & $\begin{array}{l}\text { Detection of low- } \\
\text { energy radiation }\end{array}$ \\
\hline & $\begin{array}{l}\text { Organic tissue equivalent } \\
\text { (plastics) }\end{array}$ & $\begin{array}{l}\text { Does equivalent rate } \\
\text { measurements }\end{array}$ & \\
\hline Solid State & Germanium semi-conductor & $\begin{array}{l}\text { Laboratory and field gamma } \\
\text { spectrometry and } \\
\text { spectroscopy }\end{array}$ & \\
\hline $\begin{array}{l}\text { Passive, integrating } \\
\text { electret ion } \\
\text { chamber }\end{array}$ & $\begin{array}{l}7 \mathrm{mg} / \mathrm{cm}^{2} \text { window, also } \\
\text { window-less, window area } \\
50-180 \mathrm{~cm}^{2}, \text { chamber } \\
\text { volume } 50-1,000 \mathrm{ml}\end{array}$ & & $\begin{array}{l}\text { Usable in high humidity } \\
\text { and temperature }\end{array}$ \\
\hline
\end{tabular}


Table C-2 Radiation Detectors with Applications to Gamma and X-Ray Surveys

\begin{tabular}{|c|c|c|c|c|c|}
\hline System & Description & Application & Remarks & Cost of Equipment & Cost per Measurement \\
\hline $\begin{array}{l}\text { GM survey meter with } \\
\text { gamma probe }\end{array}$ & $\begin{array}{l}\text { Thick-walled } 30 \\
\mathrm{mg} / \mathrm{cm}^{2} \text { detector }\end{array}$ & $\begin{array}{l}\text { Measure radiation levels } \\
\text { above } 0.1 \mathrm{mR} / \mathrm{hr} \text {. }\end{array}$ & $\begin{array}{l}\text { Its non-linear energy } \\
\text { response can be } \\
\text { corrected by using an } \\
\text { energy compensated } \\
\text { probe. }\end{array}$ & $\$ 400-\$ 1,000$ & $\$ 5$ \\
\hline $\begin{array}{l}\text { Pressurized ion chamber } \\
\text { (PIC) }\end{array}$ & $\begin{array}{l}\text { A highly accurate } \\
\text { ionization chamber that } \\
\text { is rugged and stable. }\end{array}$ & $\begin{array}{l}\text { Excellent for measuring } \\
\text { gamma exposure rate } \\
\text { during site remediation. }\end{array}$ & $\begin{array}{l}\text { Is used in conjunction } \\
\text { with radionuclide } \\
\text { identification } \\
\text { equipment. }\end{array}$ & $\$ 15 \mathrm{~K}-\$ 50 \mathrm{~K}$ & $\$ 50-\$ 500$ \\
\hline Electret ion chamber & $\begin{array}{l}\text { Electrostatically } \\
\text { charged disk inside an } \\
\text { ion chamber. }\end{array}$ & Gamma exposure rate & N/A, rented & Included in rental price & $\$ 8-\$ 25$ \\
\hline $\begin{array}{l}\text { Hand-held ion chamber } \\
\text { survey meter }\end{array}$ & $\begin{array}{l}\text { Ion chamber for } \\
\text { measuring higher } \\
\text { radiation levels than } \\
\text { typical background. }\end{array}$ & $\begin{array}{l}\text { Measures true gamma } \\
\text { exposure rate }\end{array}$ & $\begin{array}{l}\text { Not very useful for site } \\
\text { surveys because of high } \\
\text { detection limit above } \\
\text { background levels. }\end{array}$ & $\$ 800-\$ 1,200$ & $\$ 5$ \\
\hline $\begin{array}{l}\text { Hand-held pressurized } \\
\text { ion chamber survey } \\
\text { meter }\end{array}$ & $\begin{array}{l}\text { Ion chamber for } \\
\text { measuring higher } \\
\text { radiation levels than } \\
\text { typical background. }\end{array}$ & $\begin{array}{l}\text { Measures true gamma } \\
\text { exposure rate with more } \\
\text { sensitivity than the } \\
\text { unpressurized ion } \\
\text { chamber. }\end{array}$ & $\begin{array}{l}\text { Not very useful for site } \\
\text { surveys because of high } \\
\text { detection limit above } \\
\text { background levels. }\end{array}$ & $\$ 1,000-\$ 1,500$ & $\$ 5$ \\
\hline $\begin{array}{l}\text { Sodium Iodide survey } \\
\text { meter }\end{array}$ & $\begin{array}{l}\text { Detectors sizes up to } \\
\text { 8"x8". Used in micro } \\
\text { R-meter in smaller } \\
\text { sizes. }\end{array}$ & $\begin{array}{l}\text { Measures low levels of } \\
\text { environmental radiation. }\end{array}$ & $\begin{array}{l}\text { Its energy response is } \\
\text { not linear, so it should } \\
\text { be calibrated for the } \\
\text { energy field it will } \\
\text { measure or have } \\
\text { calibration factors } \\
\text { developed by } \\
\text { comparison with a PIC } \\
\text { for a specific site }\end{array}$ & $\$ 2 \mathrm{~K}$ & $\$ 5$ \\
\hline $\begin{array}{l}\text { FIDLER (Field } \\
\text { Instrument for Detection } \\
\text { of Low Energy } \\
\text { Radiation) } \\
\end{array}$ & $\begin{array}{l}\text { Thin crystals of NaI or } \\
\text { CsI }\end{array}$ & $\begin{array}{l}\text { Scanning of gamma } / \mathrm{X} \\
\text { radiation from } \\
\text { plutonium and } \\
\text { americium. }\end{array}$ & & $\$ 6 \mathrm{~K}-\$ 7 \mathrm{~K}$ & $\$ 10-\$ 20$ \\
\hline
\end{tabular}

MARSSIM. 1997 
Table C-2 Radiation Detectors with Applications to Gamma and X-Ray Surveys (continued)

\begin{tabular}{|c|c|c|c|c|c|}
\hline System & Description & Application & Remarks & Cost of Equipment & Cost per Measurement \\
\hline $\begin{array}{l}\text { Sodium iodide detector } \\
\text { with multichannel } \\
\text { analyzer (MCA) }\end{array}$ & $\begin{array}{l}\text { Sodium iodide crystal } \\
\text { with a large range of } \\
\text { sizes and shapes, } \\
\text { connected to a } \\
\text { photomultiplier tube and } \\
\text { MCA. }\end{array}$ & $\begin{array}{l}\text { Laboratory gamma } \\
\text { spectroscopy to } \\
\text { determine the identity } \\
\text { and concentration of } \\
\text { gamma emitting } \\
\text { radionuclides in a } \\
\text { sample. }\end{array}$ & $\begin{array}{l}\text { Sensitive for surface } \\
\text { soil or groundwater } \\
\text { contamination. } \\
\text { Analysis programs have } \\
\text { difficulty if sample } \\
\text { contains more than a } \\
\text { few isotopes. }\end{array}$ & $\$ 6 \mathrm{~K}-\$ 20 \mathrm{~K}$ & $\$ 100-\$ 200$ \\
\hline $\begin{array}{l}\text { Germanium detector } \\
\text { with multichannel } \\
\text { analyzer (MCA) }\end{array}$ & $\begin{array}{l}\text { Intrinsic germanium } \\
\text { semiconductor in p- or } \\
\text { n-type configuration and } \\
\text { without a beryllium } \\
\text { window. }\end{array}$ & $\begin{array}{l}\text { Laboratory gamma } \\
\text { spectroscopy to } \\
\text { determine the identity } \\
\text { and concentration of } \\
\text { gamma emitting } \\
\text { radionuclides in a } \\
\text { sample. }\end{array}$ & $\begin{array}{l}\text { Very sensitive for } \\
\text { surface soil or } \\
\text { groundwater } \\
\text { contamination. Is } \\
\text { especially powerful } \\
\text { when more than one } \\
\text { radionuclide is present } \\
\text { in a sample. }\end{array}$ & $\$ 35 \mathrm{~K}-\$ 150 \mathrm{~K}$ & $\$ 100-\$ 200$ \\
\hline $\begin{array}{l}\text { Portable Germanium } \\
\text { Multichannel Analyzer } \\
\text { (MCA) System }\end{array}$ & $\begin{array}{l}\text { A portable version of a } \\
\text { laboratory based } \\
\text { germanium detector and } \\
\text { multichannel analyzer. }\end{array}$ & $\begin{array}{l}\text { Excellent during } \\
\text { characterization through } \\
\text { final status survey to } \\
\text { identify and quantify the } \\
\text { concentration of gamma } \\
\text { ray emitting } \\
\text { radionuclides and in situ } \\
\text { concentrations of soil } \\
\text { and other media }\end{array}$ & $\begin{array}{l}\text { Requires a supply of } \\
\text { liquid nitrogen or a } \\
\text { mechanical cooling } \\
\text { system, as well as } \\
\text { highly trained operators. }\end{array}$ & \$40K & $\$ 100$ \\
\hline $\begin{array}{l}\text { Field x-ray fluorescence } \\
\text { spectrometer }\end{array}$ & $\begin{array}{l}\text { Uses silicon or } \\
\text { germanium } \\
\text { semiconductor }\end{array}$ & $\begin{array}{l}\text { Determining fractional } \\
\text { abundance of low } \\
\text { percentage metal atoms. }\end{array}$ & & $\$ 15 \mathrm{~K}-\$ 75 \mathrm{~K}$ & $\$ 200$ \\
\hline $\begin{array}{l}\text { Thermoluminesce } \\
\text { nce dosimeters (TLDs) }\end{array}$ & $\begin{array}{l}\text { Crystals that are } \\
\text { sensitive to gamma } \\
\text { radiation }\end{array}$ & $\begin{array}{l}\text { Measure cumulative } \\
\text { radiation dose over a } \\
\text { period of days to } \\
\text { months. }\end{array}$ & $\begin{array}{l}\text { Requires special } \\
\text { calibration to achieve } \\
\text { high accuracy and } \\
\text { reproducibility of } \\
\text { results. }\end{array}$ & $\begin{array}{l}\$ 5 \mathrm{~K}-\$ 50 \mathrm{~K} \text { for reader }+ \\
\$ 25-\$ 40 \text { per TLD }\end{array}$ & $\$ 25-\$ 125$ \\
\hline
\end{tabular}

MARSSIM, 1997 


\section{Table C-3 Radiation Detectors with Applications to Alpha Surveys}

\begin{tabular}{|c|c|c|c|}
\hline Detector Type & Detector Description & Application & Remarks \\
\hline Gas Proportional & $\begin{array}{l}<1 \mathrm{mg} / \mathrm{cm}^{2} \text { window; probe } \\
\text { area } 50 \text { to } 1000 \mathrm{~cm}^{2} \\
<0.1 \mathrm{mg} / \mathrm{cm}^{2} \text { window; } \\
\text { probe area } 10 \text { to } 20 \mathrm{~cm}^{2} \\
\text { No window (internal } \\
\text { proportional) }\end{array}$ & $\begin{array}{l}\text { Surface scanning; surface } \\
\text { contamination measurement } \\
\text { Laboratory measurement of } \\
\text { water, air, and smear samples } \\
\text { Laboratory measurement of } \\
\text { water, air, and smear samples }\end{array}$ & $\begin{array}{l}\text { Requires a supply of } \\
\text { appropriate fill gas }\end{array}$ \\
\hline Air Proportional & $\begin{array}{l}<1 \mathrm{mg} / \mathrm{cm}^{2} \text { window; probe } \\
\text { area }-50 \mathrm{~cm}^{2}\end{array}$ & $\begin{array}{l}\text { Useful in low humidity } \\
\text { conditions }\end{array}$ & \\
\hline Scintillation & $\begin{array}{l}\mathrm{ZnS}(\mathrm{Ag}) \text { scintillator; probe } \\
\text { area } 50 \text { to } 1000 \mathrm{~cm}^{2} \\
\mathrm{ZnS}(\mathrm{Ag}) \text { scintillator; probe } \\
\text { area } 10 \text { to } 20 \mathrm{~cm}^{2} \\
\text { Liquid scintillation cocktail } \\
\text { containing sample }\end{array}$ & $\begin{array}{l}\text { Surface contamination } \\
\text { measurements, smears } \\
\text { Laboratory measurement of } \\
\text { water, air, and smear samples } \\
\text { Laboratory analysis, } \\
\text { spectrometry capabilities }\end{array}$ & \\
\hline Solid State & $\begin{array}{l}\text { Silicon surface barrier } \\
\text { detector }\end{array}$ & $\begin{array}{l}\text { Laboratory analysis by alpha } \\
\text { spectrometry }\end{array}$ & \\
\hline $\begin{array}{l}\text { Passive, } \\
\text { integrating electret } \\
\text { ion chamber }\end{array}$ & $\begin{array}{l}<0.8 \mathrm{mg} / \mathrm{cm}^{2} \text { window, also } \\
\text { window-less, window area } \\
50-180 \mathrm{~cm}^{2} \text {, chamber } \\
\text { volume } 50 \text { to } 1,000 \mathrm{ml}\end{array}$ & $\begin{array}{l}\text { Contamination on surfaces, in } \\
\text { pipes and in soils }\end{array}$ & $\begin{array}{l}\text { Usable in high humidity } \\
\text { and temperature }\end{array}$ \\
\hline
\end{tabular}

MARSSIM, 1997 
Table C-4 Radiation Detectors with Applications to Alpha Surveys

\begin{tabular}{|c|c|c|c|c|c|}
\hline System & Description & Application & Remarks & Cost of Equipment & Cost per Measurement \\
\hline Alpha spectroscopy & $\begin{array}{l}\text { A system using silicon } \\
\text { diode surface barrier } \\
\text { detectors for alpha } \\
\text { energy identification } \\
\text { and quantification }\end{array}$ & $\begin{array}{l}\text { Accurately identifies } \\
\text { and measures the } \\
\text { activity of multiple } \\
\text { alpha radionuclides in a } \\
\text { thin extracted sample of } \\
\text { soil, water, or air filters }\end{array}$ & $\begin{array}{l}\text { Sample requires } \\
\text { radiochemical } \\
\text { separation or other } \\
\text { preparation before } \\
\text { counting }\end{array}$ & $\$ 10 \mathrm{~K}-\$ 100 \mathrm{~K}$ & $\$ 250-\$ 400$ \\
\hline $\begin{array}{l}\text { Alpha Scintillation } \\
\text { survey meter }\end{array}$ & $\begin{array}{l}<1 \mathrm{mg} / \mathrm{cm}^{2} \text { window, } \\
\text { probe face area } 50 \text { to } \\
1000 \mathrm{~cm}^{2}\end{array}$ & $\begin{array}{l}\text { Field measurement of } \\
\text { presence or absence of } \\
\text { alpha contamination on } \\
\text { nonporous surfaces, } \\
\text { swipes, and air filters, or } \\
\text { on irregular surfaces if } \\
\text { the degree of surface } \\
\text { shielding is known }\end{array}$ & $\begin{array}{l}\text { Minimum sensitivity is } \\
10 \mathrm{cmp} \text {, or } 1 \mathrm{cpm} \text { with } \\
\text { headphones }\end{array}$ & $\$ 1,000$ & $\$ 5$ \\
\hline Alpha Track Detector & $\begin{array}{l}\text { Polycarbonate plastic } \\
\text { sheet is placed in } \\
\text { contact with a } \\
\text { contaminated surface } \\
\text { and kept in place }\end{array}$ & $\begin{array}{l}\text { Measures gross alpha } \\
\text { surface contamination, } \\
\text { soil, activity level, or } \\
\text { the depth profile of } \\
\text { contamination }\end{array}$ & $\begin{array}{l}\text { Alpha radiation } \\
\text { produces holes that are } \\
\text { enlarged chemically. } \\
\text { Density of holes gives a } \\
\text { measure of the } \\
\text { radioactivity level }\end{array}$ & Included in rental price & $\$ 5-\$ 25$ \\
\hline Electret ion chamber & $\begin{array}{l}\text { A charged Teflon disk } \\
\text { in an open-faced ion } \\
\text { chamber }\end{array}$ & $\begin{array}{l}\text { Measures alpha or beta } \\
\text { contamination on } \\
\text { surfaces and in soil, plus } \\
\text { gamma radiation does } \\
\text { or radon concentration }\end{array}$ & $\begin{array}{l}\text { The type of radiation is } \\
\text { determined by how the } \\
\text { electret is employed, } \\
\text { e.g., the unit is kept } \\
\text { closed and bagged in } \\
\text { plastic to measure } \\
\text { gammas }\end{array}$ & $\$ 4,000-\$ 5,000$ & $\$ 8-\$ 25$ \\
\hline
\end{tabular}


Table C-4 Radiation Detectors with Applications to Alpha Surveys

(continued)

\begin{tabular}{|c|c|c|c|c|c|}
\hline System & Description & Application & Remarks & Cost of Equipment & Cost per Measurement \\
\hline $\begin{array}{l}\text { Long Range Alpha } \\
\text { Detector (LRAD) }\end{array}$ & $\begin{array}{l}\text { Im } \times 1 \mathrm{~m} \text { detector } \\
\text { measures ionization } \\
\text { inside the box. } \\
\text { Attached to tractor for } \\
\text { movement. Has } \\
\text { location finder and plots } \\
\text { graph of contamination }\end{array}$ & $\begin{array}{l}\text { Measures surface } \\
\text { contamination or soil } \\
\text { concentration at grid } \\
\text { points and plots curves } \\
\text { of constant } \\
\text { contamination. } \\
\text { Intended for large areas }\end{array}$ & $\begin{array}{l}\text { Alpha detection limit is } \\
20-50 \mathrm{dmp} / 100 \mathrm{~cm}^{2} \text { or } \\
0.4 \mathrm{~Bq} / \mathrm{g}(10 \mathrm{pCi} / \mathrm{g})\end{array}$ & $\$ 25,000$ & $\$ 80$ \\
\hline $\begin{array}{l}\text { Gas-flow proportional } \\
\text { counter (field) }\end{array}$ & $\begin{array}{l}\text { A detector through } \\
\text { which } \mathrm{P} 10 \text { gas flows } \\
\text { and which measures } \\
\text { alpha and beta radiation. } \\
<1-10 \mathrm{mg} / \mathrm{cm}^{2} \text { window, } \\
\text { probe face area } 50 \text { to } \\
100 \mathrm{~cm}^{2} \text { for hand held } \\
\text { detectors; up to } 600 \mathrm{~cm}^{2} \\
\text { if cart mounted }\end{array}$ & $\begin{array}{l}\text { Surface scanning, } \\
\text { surface activity } \\
\text { measurement, or field } \\
\text { evaluation of swipes. } \\
\text { Serves as a screen to } \\
\text { determine if more } \\
\text { nuclide-specific } \\
\text { analyses are needed }\end{array}$ & $\begin{array}{l}\text { Natural radionuclides in } \\
\text { samples can interfere } \\
\text { with the detection of } \\
\text { other contaminants. } \\
\text { Requires P10 gas }\end{array}$ & $\$ 2 \mathrm{~K}-\$ 4 \mathrm{~K}$ & $\$ 2-\$ 10 / \mathrm{m}^{2}$ \\
\hline $\begin{array}{l}\text { Gas-flow proportional } \\
\text { counter (lab) }\end{array}$ & $\begin{array}{l}\text { Windowless (internal } \\
\text { proportional) or window } \\
<0.1 \mathrm{mg} / \mathrm{cm}^{2}, \text { probe face } \\
\text { area } 10 \text { to } 20 \mathrm{~cm}^{2} \text {. May } \\
\text { have a second or guard } \\
\text { detector to reduce } \\
\text { background and MDA }\end{array}$ & $\begin{array}{l}\text { Laboratory } \\
\text { measurement of water, } \\
\text { air, and swipe samples }\end{array}$ & $\begin{array}{l}\text { Requires P10 gas. } \\
\text { Windowless detectors } \\
\text { can be contaminated }\end{array}$ & $\$ 4 \mathrm{~K}-\$ 30 \mathrm{~K}$ & $\$ 50$ \\
\hline $\begin{array}{l}\text { Liquid Scintillation } \\
\text { Counter (LSC) }\end{array}$ & $\begin{array}{l}\text { Samples are mixed with } \\
\text { LSC cocktail and the } \\
\text { radiation emitted causes } \\
\text { light pulses with } \\
\text { proportional intensity }\end{array}$ & $\begin{array}{l}\text { Laboratory analysis of } \\
\text { alpha or beta emitters, } \\
\text { including spectrometry } \\
\text { capabilities }\end{array}$ & $\begin{array}{l}\text { Highly selective for } \\
\text { alpha or beta radiation } \\
\text { by pulse shape } \\
\text { discrimination. } \\
\text { Requires LSC cocktail }\end{array}$ & $\$ 40 \mathrm{~K}$ & $\$ 50-\$ 200$ \\
\hline
\end{tabular}

MARSSIM, 1997 
Table C-5 Radiation Detectors with Applications to Beta Surveys

\begin{tabular}{|c|c|c|c|}
\hline Detector Type & Detector Description & Application & Remarks \\
\hline Gas Proportional & $\begin{array}{l}<1 \mathrm{mg} / \mathrm{cm}^{2} \text { window; probe } \\
\text { area } 50 \text { to } 1000 \mathrm{~cm}^{2} \\
<0.1 \mathrm{mg} / \mathrm{cm}^{2} \text { window; } \\
\text { probe area } 10 \text { to } 20 \mathrm{~cm}^{2} \\
\text { No window (internal } \\
\text { proportional) }\end{array}$ & $\begin{array}{l}\text { Surface scanning; surface } \\
\text { contamination measurement } \\
\text { Laboratory measurement of } \\
\text { water, air, smear, and other } \\
\text { samples } \\
\text { Laboratory measurement of } \\
\text { water, air, smear, and other } \\
\text { samples }\end{array}$ & $\begin{array}{l}\text { Requires a supply of } \\
\text { appropriate fill gas } \\
\text { Can be used for } \\
\text { measuring very low- } \\
\text { energy betas }\end{array}$ \\
\hline $\begin{array}{l}\text { Ionization } \\
\text { (non-pressurized) }\end{array}$ & $1-7 \mathrm{mg} / \mathrm{cm}^{2}$ window & $\begin{array}{l}\text { Contamination measurements; } \\
\text { skin dose rate estimates }\end{array}$ & \\
\hline Geiger-Mueller & $\begin{array}{l}<2 \mathrm{mg} / \mathrm{cm}^{2} \text { window; probe } \\
\text { area } 10 \text { to } 100 \mathrm{~cm}^{2} \\
\text { Various window thickness; } \\
\text { few } \mathrm{cm}^{2} \text { probe face }\end{array}$ & $\begin{array}{l}\text { Surface scanning; } \\
\text { contamination measurements; } \\
\text { laboratory analyses } \\
\text { Special scanning applications }\end{array}$ & \\
\hline Scintillation & $\begin{array}{l}\text { Liquid scintillation cocktail } \\
\text { containing sample } \\
\text { Plastic scintillator }\end{array}$ & $\begin{array}{l}\text { Laboratory analysis, } \\
\text { spectrometry capabilities } \\
\text { Contamination measurements }\end{array}$ & \\
\hline $\begin{array}{l}\text { Passive, } \\
\text { integrating electret } \\
\text { ion chamber }\end{array}$ & $\begin{array}{l}7 \mathrm{mg} / \mathrm{cm}^{2} \text { window, also } \\
\text { window-less, window area } \\
50-180 \mathrm{~cm}^{2} \text {, chamber } \\
\text { volume } 50 \text { to } 1,000 \mathrm{ml}\end{array}$ & $\begin{array}{l}\text { Low energy beta including } \mathrm{H}-3 \\
\text { contamination on surfaces and } \\
\text { in pipes }\end{array}$ & $\begin{array}{l}\text { Usable in high humidity } \\
\text { and temperature }\end{array}$ \\
\hline
\end{tabular}

MARSSIM, 1997 


\section{Table C-6 Radiation Detectors with Applications to Beta Surveys}

\begin{tabular}{|c|c|c|c|c|c|}
\hline System & Description & Application & Remarks & Cost of Equipment & Cost per Measurement \\
\hline $\begin{array}{l}\text { GM survey meter with } \\
\text { beta pancake probe }\end{array}$ & $\begin{array}{l}\text { Thin } 1.4 \mathrm{mg} / \mathrm{cm}^{2} \\
\text { window detector, probe } \\
\text { area } 10 \text { to } 100 \mathrm{~cm}^{2}\end{array}$ & $\begin{array}{l}\text { Surface scanning of } \\
\text { personnel, working } \\
\text { areas, equipment, and } \\
\text { swipes for beta } \\
\text { contamination. } \\
\text { Laboratory } \\
\text { measurement of swipes } \\
\text { when connected to a } \\
\text { scaler }\end{array}$ & $\begin{array}{l}\text { Relatively high } \\
\text { detection limit making it } \\
\text { of limited value in final } \\
\text { status surveys }\end{array}$ & $\$ 400-\$ 1,500$ & $\$ 5-\$ 10$ \\
\hline $\begin{array}{l}\text { Gas-flow proportional } \\
\text { counter (field) }\end{array}$ & $\begin{array}{l}\text { A detector through } \\
\text { which } P 10 \text { gas flows } \\
\text { and which measures } \\
\text { alpha and beta radiation. } \\
<1-10 \mathrm{mg} / \mathrm{cm}^{2} \text { window, } \\
\text { probe face area } 50 \text { to } \\
100 \mathrm{~cm}^{2}\end{array}$ & $\begin{array}{l}\text { Surface scanning, } \\
\text { surface activity } \\
\text { measurement, or field } \\
\text { evaluation of swipes. } \\
\text { Serves as a screen to } \\
\text { determine if more } \\
\text { nuclide-specific } \\
\text { analyses are needed }\end{array}$ & $\begin{array}{l}\text { Natural radionuclides in } \\
\text { samples can interfere } \\
\text { with the detection of } \\
\text { other contaminants. } \\
\text { Requires P10 gas, but } \\
\text { can be disconnected for } \\
\text { hours }\end{array}$ & $\$ 2 \mathrm{~K}-\$ 4 \mathrm{~K}$ & $\$ 2-\$ 10 / \mathrm{m}^{2}$ \\
\hline $\begin{array}{l}\text { Gas-flow proportional } \\
\text { counter (lab) }\end{array}$ & $\begin{array}{l}\text { Windowless (internal } \\
\text { proportional) or window } \\
<0.1 \mathrm{mg} / \mathrm{cm}^{2}, \text { probe face } \\
\text { area } 10 \text { to } 20 \mathrm{~cm}^{2} \text {. May } \\
\text { have a second or guard } \\
\text { detector to reduce } \\
\text { background and MDA }\end{array}$ & $\begin{array}{l}\text { Laboratory } \\
\text { measurement of water, } \\
\text { air, and swipe samples }\end{array}$ & $\begin{array}{l}\text { Requires P10 gas. } \\
\text { Windowless detectors } \\
\text { can be contaminated }\end{array}$ & $\$ 4 \mathrm{~K}-\$ 30 \mathrm{~K}$ & $\$ 50$ \\
\hline $\begin{array}{l}\text { Liquid Scintillation } \\
\text { Counter (LSC) }\end{array}$ & $\begin{array}{l}\text { Samples are mixed with } \\
\text { LSC cocktail and the } \\
\text { radiation emitted causes } \\
\text { light pulses with } \\
\text { proportional intensity }\end{array}$ & $\begin{array}{l}\text { Laboratory analysis of } \\
\text { alpha and beta emitters, } \\
\text { including spectrometry } \\
\text { capabilities }\end{array}$ & $\begin{array}{l}\text { Highly selective for } \\
\text { alpha and beta radiation } \\
\text { by pulse shape } \\
\text { discrimination. } \\
\text { Requires LSC cocktail }\end{array}$ & $\$ 20 \mathrm{~K}-\$ 70 \mathrm{~K}$ & $\$ 100-\$ 200$ \\
\hline
\end{tabular}

MARSSIM, 1997 
Table C-7 Radiation Detectors with Applications to Radon Surveys

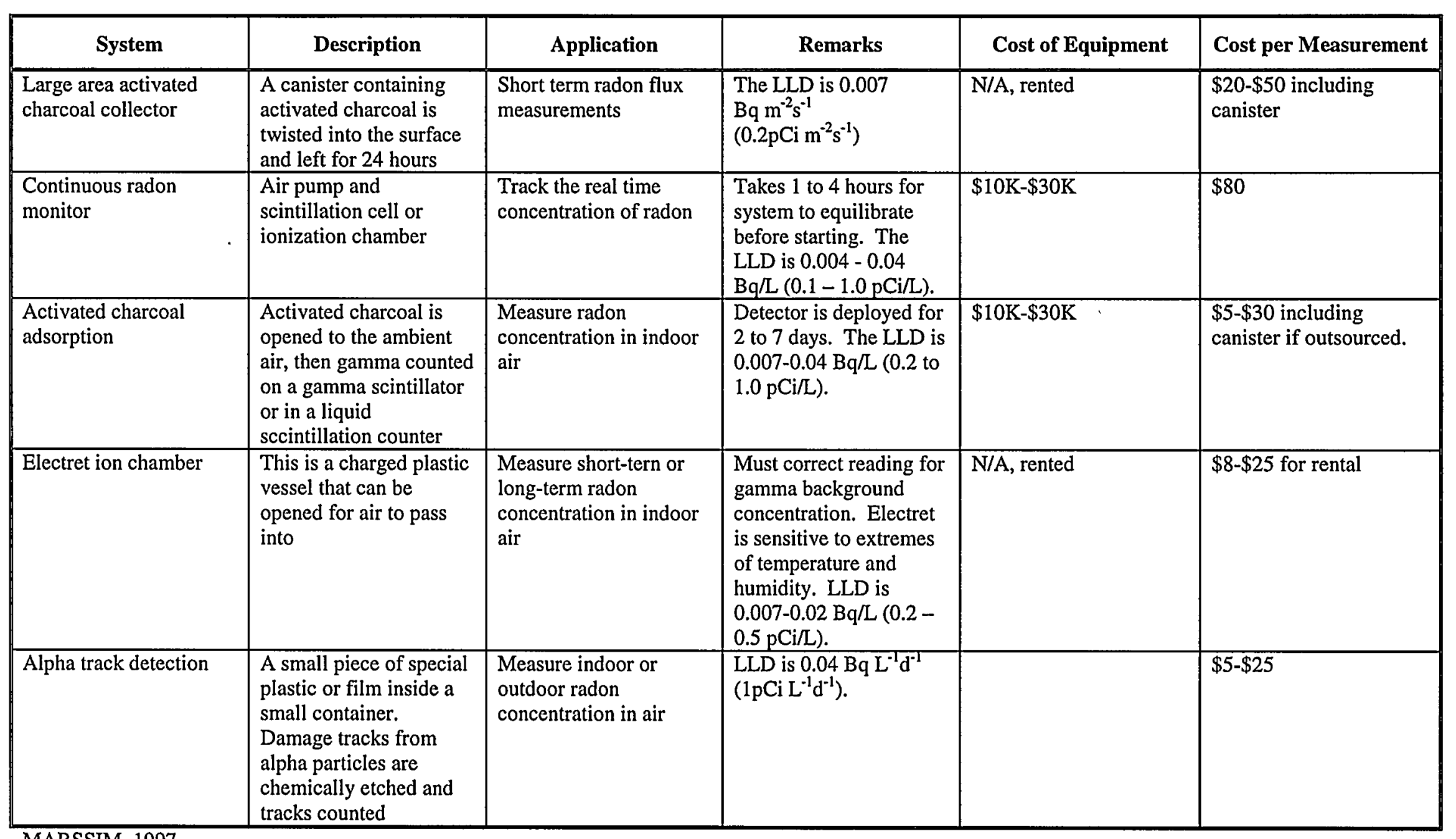

MARSSIM, 1997 
Table C-8 Systems that Measure Atomic Mass or Emissions

\begin{tabular}{|c|c|c|c|c|c|}
\hline $\begin{array}{l}\text { LA-ICP-AES (Laser } \\
\text { Ablation Inductively } \\
\text { Coupled Plasma Mass } \\
\text { Spectrometer) }\end{array}$ & $\begin{array}{l}\text { Vaporizes and ionizes } \\
\text { the surface material, } \\
\text { then measures the mass } \\
\text { of the resulting atoms }\end{array}$ & $\begin{array}{l}\text { Live time analysis of } \\
\text { radioactive } U \text { and } T h \\
\text { contamination in the } \\
\text { field }\end{array}$ & $\begin{array}{l}\text { Requires expensive } \\
\text { equipment and skilled } \\
\text { operators. More } \\
\text { sensitive than LA-ICP- } \\
\text { AES. LLD is } 0.6 \mathrm{~Bq} / \mathrm{g} \\
\left(15 \mathrm{pCi} / \mathrm{g} \text { ) for }{ }^{230} \mathrm{Th}\right.\end{array}$ & $>\$ 1,000,000$ & $>\$ 4,000$ \\
\hline $\begin{array}{l}\text { Chemical speciation } \\
\text { laser ablation/mass } \\
\text { spectrometer }\end{array}$ & $\begin{array}{l}\text { A laser changes the } \\
\text { sample into an aerosol } \\
\text { that it analyzed with a } \\
\text { mass spectrometer }\end{array}$ & $\begin{array}{l}\text { Analyze organic and } \\
\text { inorganic species with } \\
\text { high sensitivity and } \\
\text { specificity }\end{array}$ & $\begin{array}{l}\text { Volatilized samples can } \\
\text { be carried hundreds of } \\
\text { feet to the analysis area }\end{array}$ & $>\$ 1,000,000$ & $>\$ 4,000$ \\
\hline
\end{tabular}




\section{APPENDIX D. CHORNOBYL TSA PROJECT -UPDATED MARCH 31, 1999}

\begin{tabular}{|c|c|c|c|}
\hline Assignment/Action & Person(s) & Due Date & Comments \\
\hline \multicolumn{4}{|l|}{ Phase 0: Background Discussions } \\
\hline $\begin{array}{l}\text { 1) Exchange Email with Glygalo and Nosovsky to define scope } \\
\text { of Pilot. }\end{array}$ & Hund & July 22,1998 & Done \\
\hline \multicolumn{4}{|l|}{ Phase 1: Activity Planning } \\
\hline $\begin{array}{l}\text { 2) Conduct interviews with PNNL staff to understand } \\
\text { decommissioning plans and activities and the Plant and to } \\
\text { determine possible scope of Pilot. Write up notes from these: } \\
\text { a) Steve Short } \\
\text { b) Mikal McKinnon }\end{array}$ & Hund & $\begin{array}{l}\text { August } 21,1998 \\
\text { August } 25,1998\end{array}$ & $\begin{array}{l}\text { Done } \\
\text { Done }\end{array}$ \\
\hline 3) Design interview guide for Ukrainian interviews & Hund & October 15,1998 & Done \\
\hline $\begin{array}{l}\text { 4) Conduct interviews with staff and write up notes on these: } \\
\text { a) Seyda } \\
\text { b) Nosovsky } \\
\text { c) Skripov }\end{array}$ & Hund & October $20-23,1998$ & Done \\
\hline $\begin{array}{l}\text { 5) Interview regulator community and OSAT contractor, write } \\
\text { up notes on these: } \\
\text { a) Ms. Bogdan } \\
\text { b) Oleg Sevastiuk } \\
\text { c) Jean-Jacques Doublecourt }\end{array}$ & $\begin{array}{l}\text { Andrei Gluhkov } \\
\text { Andrei Glhkov } \\
\text { Aleksey Milchakov }\end{array}$ & $\begin{array}{l}\text { Not possible } \\
\text { December 21, } 1998 \\
\text { Not possible }\end{array}$ & Done \\
\hline 6) Analyze results from interviews & Hund & January 4,1999 & Done \\
\hline $\begin{array}{l}\text { 7) Develop a draft Pilot Scope Position Paper to accompany } \\
\text { this Work Plan }\end{array}$ & Hund & November 25,1998 & $\begin{array}{l}\text { Done, distributed to within } \\
\text { PNNL }\end{array}$ \\
\hline $\begin{array}{l}\text { 8) Have the Scope Paper and Work Plan reviewed: } \\
\text { a) Roger Anderson } \\
\text { b) Steve Short, Andrei Gluhkov, Dennis Kried } \\
\text { c) Nosovsky and Glygalo }\end{array}$ & Hund & $\begin{array}{l}\text { December } 4,1998 \\
\text { December } 18,1998 \\
\text { February } 8,1999 \\
\end{array}$ & $\begin{array}{l}\text { Done } \\
\text { Done }\end{array}$ \\
\hline 9) Revise the Scope Paper and Work Plan based on comments & Hund & February 12,1999 & February 12,1999 \\
\hline
\end{tabular}




\begin{tabular}{|c|c|c|c|}
\hline Assignment/Action & Person(s) & Due Date & Comments \\
\hline $\begin{array}{l}\text { 10) Have the Scope Paper and Work Plan agreed to (finalize } \\
\text { it): } \\
\text { a) Roger Anderson } \\
\text { b) Nosovsky and Glygalo }\end{array}$ & Hund & $\begin{array}{l}\text { February 16, } 1999 \\
\text { February 23, } 1999\end{array}$ & $\begin{array}{l}\text { February 16, } 1999 \\
\text { February 25, } 1999 \text { (Nosovsky) }\end{array}$ \\
\hline $\begin{array}{l}\text { 11) Brief relevant PNNL staff and others recommended about } \\
\text { the Pilot scope. }\end{array}$ & Hund & February 26,1999 & February 19,1999 \\
\hline $\begin{array}{l}\text { 12) Recommend one or two staff from Ukraine to come the US } \\
\text { and conduct the Pilot }\end{array}$ & Hund & December 18, 1998 & $\begin{array}{l}\text { Two candidates already } \\
\text { suggested by Glygalo and } \\
\text { Nosovsky. - Dec. 18, 1998 }\end{array}$ \\
\hline $\begin{array}{l}\text { 13) Arrange to have the staff come and set up the necessary } \\
\text { logistics for their stay. Have them arrive in Seattle. }\end{array}$ & $\begin{array}{l}\text { Hund/ Warden /Charters/ } \\
\text { Jennifer Carpenter }\end{array}$ & February 27,1999 & February 25,1999 \\
\hline $\begin{array}{l}\text { 14) Develop lists of key words, topics, documents, } \\
\text { organizations, scientists, engineers }\end{array}$ & Milchakov and Poralo & March 5, 1999 & March 5, 1999 \\
\hline \multicolumn{4}{|l|}{ Phase 2: Preparation and Collection of Data } \\
\hline $\begin{array}{l}\text { 15) Identify current databases, tools, resources used by ChnPP, } \\
\text { the Chornobyl Center, and the Slavutych Laboratory to identify } \\
\text { decommissioning technologies and approaches }\end{array}$ & Milchakov and Poralo & March 5, 1999 & March 5, 1999 \\
\hline $\begin{array}{l}\text { 16) Collect secondary data, using key work searches and } \\
\text { electronic data bases, on: } \\
\text { a) radiation survey technologies relevant to decommissioning } \\
\text { reactors 1-3 at ChNPP (primary focus on Unit 1). } \\
\text { b) new methods for using these technologies (e.g., software } \\
\text { systems) } \\
\text { c) relevant regulations used in other countries for radiation } \\
\text { survey work under such conditions. }\end{array}$ & $\begin{array}{l}\text { Milchakov, Poralo, and } \\
\text { Hund, use Library }\end{array}$ & March 12, 1999 & March 12, 1999 \\
\hline 17) Conduct patent search using output of search from \#16 & $\begin{array}{l}\text { Pilot team with Hanford } \\
\text { Technical Library }\end{array}$ & March 16, 1999 & March 16, 1999 \\
\hline 18) Collect any easily accessible primary data (human sources) & Pilot team and Hund & March 19, 1999 & March 19, 1999 \\
\hline $\begin{array}{l}\text { 19) Distill data collected and verify utility of data (move to } \\
\text { Phase 3: Information Development for analysis) }\end{array}$ & Pilot team and Hund & March 19, 1999 & March 19, 1999 \\
\hline
\end{tabular}




\begin{tabular}{|c|c|c|c|}
\hline Assignment/Action & Person(s) & Due Date & Comments \\
\hline \multicolumn{4}{|l|}{ Phase 3: Intelligence Development } \\
\hline $\begin{array}{l}\text { 20) Analyze results of output from Phase 2. Compare and } \\
\text { contrast the following attributes for the relevant technologies } \\
\text { and application systems for the technologies identified: } \\
\text { Technology provider(s), } \\
\text { - time required to take one measurement, } \\
\text { - complexity of the instrument, } \\
\text { - the non-destructive assay (NDA) ability of a device, } \\
\text { corformance, } \\
\text { - experience in applying the technology (where and how } \\
\text { applied, advantages and disadvantages). }\end{array}$ & Pilot team and Hund & $\begin{array}{l}\text { March 26, } 1999 \\
\text {. }\end{array}$ & $\begin{array}{l}\text { March 29, } 1999 \text { (more } \\
\text { analysis could be done here) }\end{array}$ \\
\hline $\begin{array}{l}\text { 21) Conduct business analysis of the companies providing the } \\
\text { technologies and associated application systems }\end{array}$ & Pilot team and Hund & March 26, 1999 & $\begin{array}{l}\text { March 26, } 1999 \text { (more work } \\
\text { could be done here) }\end{array}$ \\
\hline $\begin{array}{l}\text { 22) Conduct market analysis of the customers in Ukraine (and } \\
\text { the rest of Eastern Europe) for these technologies and systems. }\end{array}$ & Pilot team and Hund & March 26, 1999 & $\begin{array}{l}\text { March 26, } 1999 \text { (just focused } \\
\text { on ChNPP) }\end{array}$ \\
\hline $\begin{array}{l}\text { 23) Conduct the analysis of the regulations other Nations are } \\
\text { using in this area }\end{array}$ & Pilot team and Hund & March 26, 1999 & $\begin{array}{l}\text { March } 19,1999 \text { (through } \\
\text { IAEA publication) }\end{array}$ \\
\hline
\end{tabular}




\begin{tabular}{|c|c|c|c|}
\hline Assignment/Action & Person(s) & Due Date & Comments \\
\hline \multicolumn{4}{|l|}{ Phase 4: Deliver Products/Support Product Use } \\
\hline $\begin{array}{l}\text { 24) Deliver analysis to PNNL staff } \\
\text { - } \text { Roger Anderson } \\
\text { - } \text { Andrei Gluhkov } \\
\text { - } \text { Steve Short } \\
\text { - Laurin Dodd } \\
\text { - } \text { Dave Robertson } \\
\text { - Tom Wood } \\
\end{array}$ & Pilot team & March 30, 1999 & $\begin{array}{l}\text { March 30, } 1999 \text { (audience } \\
\text { included many more experts } \\
\text { from other Hanford } \\
\text { organizations who served as } \\
\text { primary sources for the team) }\end{array}$ \\
\hline \multicolumn{4}{|l|}{ Phase 5: Lessons Learned/ Recommendations } \\
\hline $\begin{array}{l}\text { 25) Develop lessons learned-- From U.S.'s and Ukrainian } \\
\text { perspective }\end{array}$ & Hund and Pilot lead & March 31, 1999 & March 30, 1999 \\
\hline \multicolumn{4}{|l|}{ Phase 6: Communication of Results/ Recommendation } \\
\hline $\begin{array}{l}\text { 26) Deliver analysis to SLIRT and Chornobyl Center (Mr. } \\
\text { Nosovsky, and interested staff, and Dr. Glygalo, and interested } \\
\text { staff). }\end{array}$ & Pilot team & April 16, 1999 & $\begin{array}{l}\text { Commitment by several } \\
\text { PNNL staff (Jim Hartley and } \\
\text { George Vargo) was offered to } \\
\text { help expedite this }\end{array}$ \\
\hline
\end{tabular}

